\title{
Um tradutor da aldeia na cidade e da cidade na aldeia
}

\author{
Xadalu Tupã Jekupé ${ }^{1}$ Inês de Araujo² , Tania Queiroz ${ }^{3}$, Ana Clara Souza ${ }^{4}$, Racquel Fontenele ${ }^{5}$, \\ Rafaella Souza ${ }^{6}$ e Sofia Skymma?.
}

Resumo: Entrevista realizada pelas autoras com o artista indígena Xadalu Tupã Jakupé, relacionando suas intervenções artísticas e seu trânsito entre cidade e aldeias a modos de estabelecer contato entre a arte e seu público através do contágio.

Palavras-chave: Arte indígena, ativismo, intervenção urbana, grafite.

\section{A translator of native community in the city and from the city to native community}

Abstract: Interview conducted by the authors with the indigenous artist Xadalu Tupã Jakupé, relating their artistic interventions and their transit between the cities and indigenous villages to ways of establishing contact between art and its audience through contagion.

Kevwords: Indiaenous art. activism. urhan intervention. araffiti.

1 Xadalu Tupã Jekupé é artista visual urbano com uma obra que transita entre intervenções nas ruas e exposições em museus, galerias e centros culturais. Sua produção diversificada mescla diferentes meios e linguagens como os adesivos da sticker art, a gravura, a pintura, a fotografia e o objeto. As questões indígenas acompanham seu trabalho, que transita entre a cidade e as aldeias.

2 É artista e pesquisadora, professora adjunta do Instituto de Artes e do Programa de Pós-graduação em Artes da Uerj. Vínculo institucional: professora na Universidade do Estado do Rio de Janeiro, São Francisco Xavier, 524 - Maracanã, Rio de Janeiro, R.J, 20943000. E-mail: ines.arj@gmail.com ORCID ID: https://orcid.org/0000-0002-7056-1386 Lattes ID: http://lattes.cnpq. br/2689541605877857. Rio de Janeiro, Brasil.

3 É artista, arquiteta e educadora. Doutoranda e Mestre em Arte e Cultura Contemporânea pela Universidade do Estado do Rio de Janeiro. .Vínculo institucional: Universidade do Estado do Rio de Janeiro. E-mail: taniaqueiroz3@gmail.com ORCID ID: https:// orcid.org/0000-0002-0476-9357. Lattes ID: http://lattes.cnpq.br/0370928923427871. Rio de Janeiro, Brasil.

4 É artista e estudante de Artes Visuais na Universidade do Estado do Rio de Janeiro, bolsista CNPq. Vínculo institucional: graduanda pela Universidade do Estado do Rio de Janeiro. E-mail: growclara@gmail.com. ORCID iD: https://orcid.org/0000-00027705-8425. ID Lattes: 241915137772234. Rio de Janeiro, Brasil.

5 É graduanda em Arte Visuais pela Universidade do Estado do Rio de Janeiro. Bolsista FAPERJ. Trabalha com serigrafia, apropriação, desenho e colagem. Vínculo institucional: Universidade do Estado do Rio de Janeiro. E-mail: racquel3stm@hotmail.com. ORCID: https://orcid.org/0000-0002-8215-1691. Lattes iD: http://lattes.cnpq.br/5788242000801102. Rio de Janeiro, Brasil.

6 É bacharel em Artes Visuais pela Universidade do Estado do Rio de Janeiro, mestranda no PPGArtes da UERJ. Vínculo institucional: Universidade do Estado do Rio de Janeiro. E-mail: ellafranzrafa@gmail.com. ORCID: https://orcid.org/0000-0002-42720925. Lattes iD: http://lattes.cnpq.br/6662499201199365. Rio de Janeiro, Brasil.

7 É artista, concluinte em Artes Visuais pela Unive do Estado do Rio de Janeiro. Vínculo institucional: Universidade do Estado do Rio de Janeiro. E-mail: sofiaskmma@gmail.com. ORCID: https://orcid.org/0000-0003-2600-7094. Lattes iD: http://lattes.cnpq. br/6169299318917498. Rio de Janeiro, Brasil. 
Entrevista realizada no dia 25 de outubro de 2020, com Xadalu Tupã Jekupé, por Inês de Araujo e Tania Queiroz, com a participação de Ana Clara Souza, Racquel Fontenele, Rafaella Souza e Sofia Skymma.

Tania Queiroz: Xadalu, seria interessante se você pudesse começar nos contando como se dá seu contato com a arte, como seu trabalho se relaciona com suas questões identitárias e estabelece essa comunicação entre cidade e aldeia.

Xadalu Tupã Jekupé: Antes de vir para Porto Alegre a gente morava na beira do rio, porque no interior é diferente da cidade, as pessoas que moram no rio são as pessoas mais pobres, que ficam mais afastadas, e as pessoas mais ricas ficam no centro da cidade. Quando a gente tem uma noção da capital, vê que na beira do Guaíba moram as pessoas mais ricas, têm esse privilégio de ter contato com a água. Antes de sair de Alegrete eu tinha contato diariamente com o rio, eu mergulhava no rio, pegava as frutas no cacho, no pé.

Quando a gente chega na cidade fica um pouco desorientado. A minha mãe foi procurar trabalho, ela sabia ler e juntar as palavras, bem pouco. A gente acabou ficando num barraco na periferia, mas em situação de rua, porque eu juntava latinhas e papelão, e a gente sobreviveu por muito tempo disso. Quando eu andava nas ruas eu via tudo aquilo acontecer e não sabia direito o que se passava, mas eu sempre frequentei a escola, porque na escola a gente se alimentava. Eu acho que o caráter da rua me deixou muito sagaz na forma de sintetizar as coisas, porque na rua tu tem que pensar rápido pra sobreviver. Eu dormia em meio a papelões e tinha que saber os horários que as pessoas colocavam lixo pra pegar as latinhas, e principalmente observar e respeitar os sinais da rua. Porque sensibilidade eu trouxe de onde eu vim, que era da beira do rio, do fogo, de onde eu vivia no Alegrete. Mas a cidade me deixou muito sagaz. Rápido de entender as coisas.

Eu acho que a grande faculdade da vida foi dentro da periferia, com as pessoas do tráfico, na comunidade, na qual a gente consegue absorver tudo aquilo que o mundo vai oferecer, da maneira que ele oferece pra gente que é pobre, que está dentro de um contexto de periferia, numa época em que não existiam cotas, não existia nada. O que existia era curso técnico pra uma galera privilegiada. A gente nunca prospectou ir pra universidade, a gente vivia no tempo do Fernando Henrique, imagina, nunca. Era uma coisa muito violenta pra nós, a nossa realidade era se formar e conseguir um trabalho, e pronto. Eu acho que a periferia me lapidou dessa maneira, de ter uma ética e principalmente de ter atitude. 
Quando eu era pequeno, na minha chegada na periferia, eu estava brincando com as crianças e aí o patrão da comunidade, o chefe do tráfico, mandou me chamar. Eu me lembro muito bem porque ele era um cara que - nossa! - ele matou muita gente, ele era conhecido por ser um matador, mas todo mundo na comunidade admirava ele. Ele tinha uma cadeira de rodas e três caras com ele, e ele falou pra mim: "Tudo bem? Como é que tá tua mãe? E tua avó? E tu tá andando muito na rua? Como é que tá a rua?" Eu falei: "Ah, não sei, eu junto lata..." E ele: "Pense assim, na rua vale mais uma mente articulada do que uma arma engatilhada, porque tu não tem arma, então tem que ter uma mente muito articulada e agora tu entrou no teste." Eu me assustei, e ele: "Tu não vai sair daqui porque tu entrou no teste. Imagina, estamos dentro do presídio, eu, tu e os meus comparsas e agora tu tá preso, cara, tá fudido, tá aqui e o cara da facção do lado quer que tu vá pro pau de arara, é tu que vai. E aí? Quem é que vai pro pau de arara? Será que eu? É tu? E aí, cara, o que que tu vai fazer? O cara vai te botar no pau de arara." E aí ele pegou nos meus braços e falou assim: "Cara, tu não vai pro pau de arara, tu tem que olhar pra cara do cara e falar assim 'vai tu pro pau de arara, eu não vou pro pau de arara'." Aí ele pegou meu rosto e falou: "Na rua é atitude, atitude. Só a atitude vai te livrar de coisas que as pessoas vão te impor e tu não vai precisar matar ninguém pra isso, só vai precisar ser inteligente e ter atitude", e aquela conversa acabou. Duas semanas depois ele morreu, arrancaram todos os dedos dele, e aquilo ficou comigo, sabe, atitude, e depois daquela conversa eu acredito que a minha cabeça mudou completamente.

Eu comecei a ficar com muita raiva, e comecei a ficar muito maldoso dentro do ambiente urbano, e em pouco tempo eu estava fazendo pequenos furtos. Então, um dia, eu pensei bem, se aquilo era aquilo, e resolvi virar gari. Eu já tinha contato com o pessoal da pichação, porque na comunidade a gente acaba tendo contato é com a pichação. O grafite aqui em Porto Alegre demorou muito a chegar, então, mesmo que tu não piche, está junto, e se está junto, faz parte, porque quando um é pego todo mundo é pego.

Um dia eu ganhei a oportunidade de trabalhar numa serigrafia por almoço, por um prato de comida e mais um dinheiro, e acabei aprendendo a fazer serigrafia, muito inspirado no elemento do grafite, que depois eles troca- 
ram por adesivo, o sticker. ${ }^{1} \mathrm{O}$ sticker começou assim, como uma forma de troca do movimento do grafite. Quando a gente fala do grafite é obrigado a lembrar que o grafite só é chamado de grafite no Brasil, que o distingue de pichação, porque em qualquer lugar do mundo eles chamam de grafite, que é o ato da intervenção, sendo oficial ou não. Isso vai depender da vertente em que a gente vai acreditar.

Então eu comecei a fazer adesivos e sempre tive essa coisa do indígena por causa das minhas avós, da minha bisavó, mas mais ainda pelo que nas aulas de história o professor dizia - estava tudo errado, ele dizia que aquilo não era real. E vendo nas ruas de Porto Alegre a população em situação vulnerável, imagina que isso era em 1994, e até hoje. Digamos que hoje está um pouco melhor, porque as pessoas estão se cobrando mais. A gente vivia numa época de ignorância invisível, hoje a gente começou a tensionar as coisas. A primeira imagem que eu coloquei foi essa imagem que uso até hoje, que eu criei com a ajuda de uma pessoa que sabia mexer no computador. ${ }^{2}$ A primeira produção foi de 100 mil adesivos, eu acho, que coloquei em Porto Alegre em menos de um mês. Imagina que em um mês eu povoei a cidade com os adesivos.

Inês de Araujo: E você já conhecia muito a cidade. A cidade já estava na palma da sua mão, não?

Figura 1

Fabio Pinheiro

Xadalu Tupã

Jekupé em

seu ateliê de seri-

grafia, 2010.

Fonte: acervo

pessoal

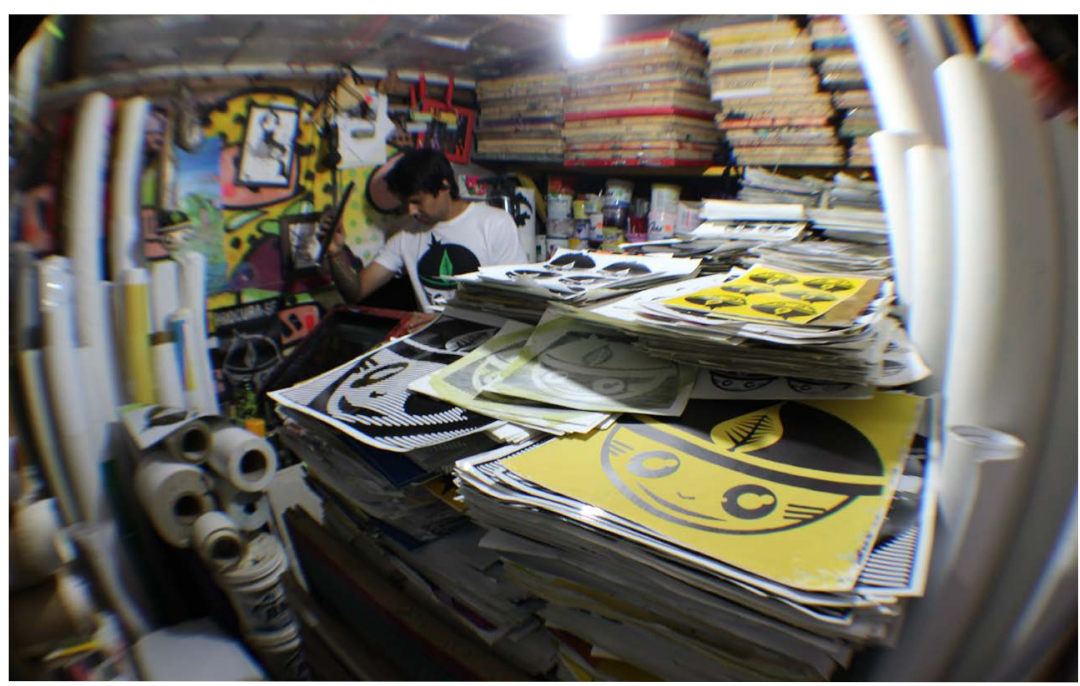

1 Sticker (adesivo, em inglês) é uma forma de arte de rua que surgiu na sequência dos movimentos da arte urbana e do grafite. Em vez de pintar as paredes, os artistas colam adesivos e cartazes.

2 Refere-se à imagem do personagem índio Xadalu. 
XTJ: O que foi muito valioso pra mim, porque eu já era acostumado a dormir na rua. Teve épocas que eu virava colando adesivos, cinco dias sem dormir, sem tomar banho, e a minha mãe pensou que eu estava maluco, eu só voltava, pegava e saía, pregava e perambulava, porque era uma coisa que eu já estava acostumado. Eu acho que isso me ajudou bastante, porque as pessoas já me conheciam no Centro da cidade, e quem é da rua sabe quem é da rua. Por mais que eu esteja vestido com uma camisa legal, a pessoa te conhece num "boa noite". Eu acho que algumas formalidades, pequenos sinais que as pessoas acabam sabendo se tu está confortável naquele lugar ou não, porque se não está confortável, não é dali, pode ter certeza, ou quer fazer algo ali.

Comecei a replicar essa imagem do indiozinho com a ideia de repovoar os indígenas que já moraram na cidade. Era uma coisa bem básica, não sabia de etnia, não sabia nada, nada, nada. E eu colei tanto, que na primeira semana saiu no jornal, pensando que era ponto de tráfico de drogas... E aí um amigo me perguntou assim: "Tu sabe o que tu tá fazendo?", e eu falei que não. "O nome disso é sticker art." ${ }^{3}$ Ele sabia que era oriundo do grafite e que já tinha virado um movimento. Ele começou a colar comigo, mas ele já era uma pessoa um pouco conhecida no meio do grafite - o nome dele é Marcelo Pax. Ele começou a me explicar que existia uma rede social chamada Flickr, e na minha comunidade tinha um programa de computadores que tu dava um litro de leite e podia ficar uma hora. O leite ia pra creche das crianças, e ninguém se opunha a dar o leite das crianças. Aí eu entrei para o Flickr. Na época, comparado aos dias de hoje, era muito puro, porque era uma coisa de descobrir; hoje a gente já sabe como funciona.

IA: Quando foi isso, Xadalu? Você lembra mais ou menos? Anos 1990?

XTJ: Eu acho que a coisa do adesivo começou em 2002, 2003, mas fui conhecer a Internet em 2007, na primeira postagem do Flickr. Eu comecei a colar os adesivos, fiz aquela primeira foto e postei no Flickr. Tu botava a foto em grupos de stickers, que eram poucos mas eram muito grandes. Eu coloquei uma foto que era um corredor com mais de 30 mil adesivos, o corredor da minha casa mesmo. Artistas do mundo inteiro começaram a comentar, comentar, comentar. Eu não sabia inglês e usei o tradutor on-line e falava com o pessoal, e fui alimentando essa rede. Era muito viciante, 
porque tu mandava a correspondência, eles acabavam recebendo no país e colando no lugar, sabe? E em pouco tempo o adesivo já estava presente em mais de sessenta países. Então foi tudo rápido.

Figura 2 Xadalu Tupã Jekupé Indiozinho Xadalu, s/d

Dimensões variadas.

Foto:

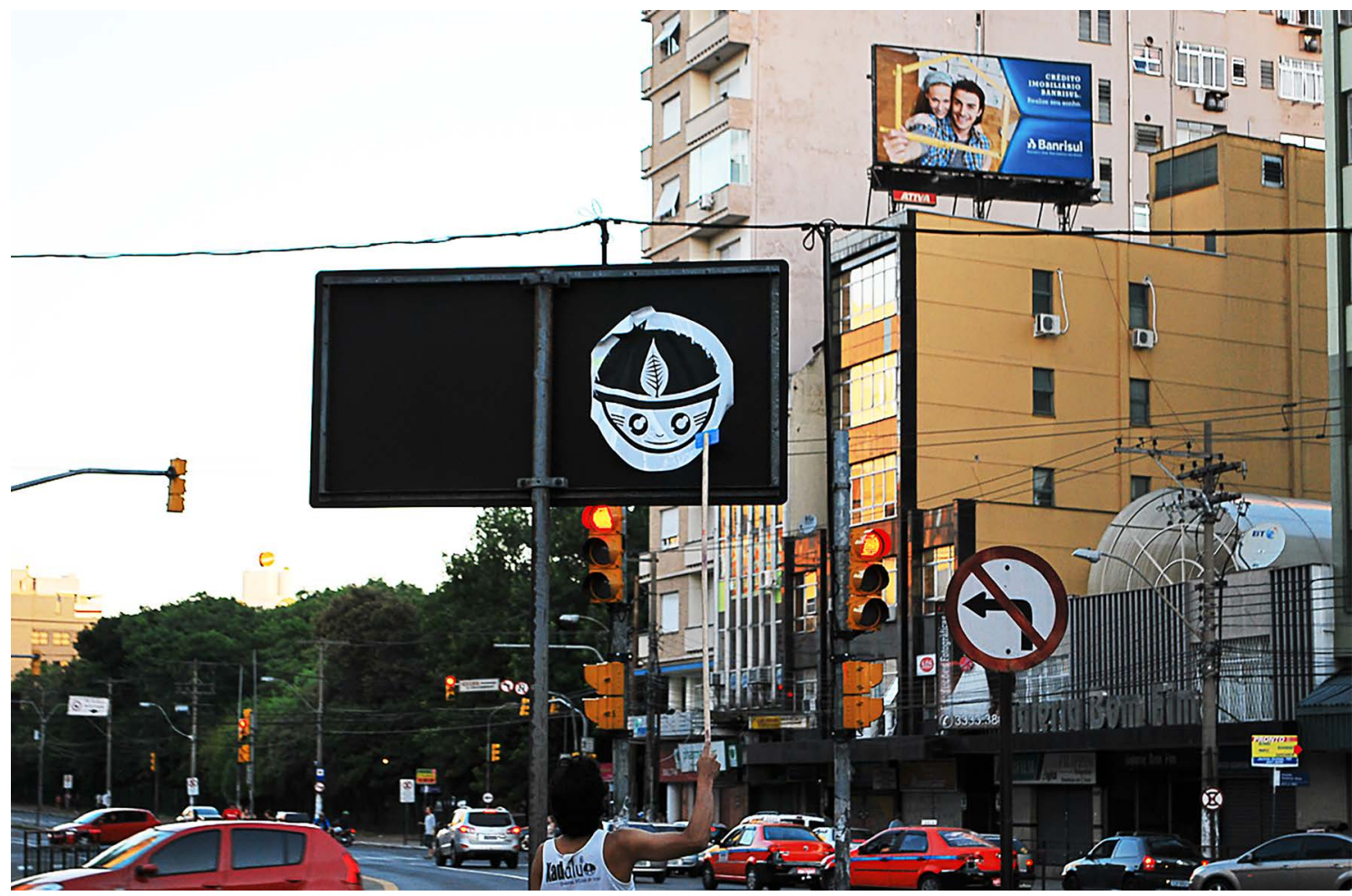

IA: É interessante você dizer isso, a gente não sabia como tinha se espalhado, se tinha se espalhado sozinho...

XTJ: Não, nunca vai ser, não teria como. Logo consegui uma grande força no que eu fazia porque eu era muito respeitado, porque eu era um mestre na serigrafia, tinha adesivos com quinze cores em serigrafia.

IA: É dificílimo!

XTJ: E tudo no registro. Na Alemanha os caras piravam porque lá é tudo preciso. Eu aprendi trabalhando, os caras [referindo-se à equipe da gráfica em que trabalhava] faziam aquilo como trabalho normal, nem era arte pra eles. Eu peguei essa época do fotolito, de desenhar no fotolito, o que eu faço ainda, de encaixar as cores na mesa de luz, então essa didática tornou muito fácil o entendimento pra depois levar pra aldeia. Mas, enfim, eu comecei a espalhar esses adesivos pela Internet, mandando por carta. Foi 
criado um filme depois, bem mais tarde, se chama Sticker Connection, ${ }^{4}$ onde artistas do mundo inteiro falam sobre mim. Na real, artistas do Japão, de Angola, Estados Unidos, uma galera que a gente conseguiu juntar. Fiquei mais conhecido no mundo do sticker, e enquanto estava rolando esse movimento de expansão mundial de adesivos eu contaminava a cidade de uma maneira bizarra e as pessoas não entendiam, porque o indiozinho era uma imagem sozinha que aparecia na rua e tomava conta.

Tem uma pessoa aqui na cidade que começou a colar adesivos em 1969, o José Toniolo, que cola também viral. Tem relato de que quando ele saiu da cadeia - foi preso porque ele pichava e colava - ele disse: "Perdi o lugar, vou ter que conhecer esse cara..." Ele cola adesivos até hoje, tem 75 anos, eu acho. E acabou se aproximando de mim. Ele disse que ficou impressionado como eu colava de uma forma massiva.

IA: Sim, a gente se impressionou muito também. E você precisa carregar, a gente sabe. Tem o peso também, não dá pra fazer muito rápido, porque precisa carregar o material.

XTJ: O negócio é pegar ônibus. Eu pegava sete da noite e voltava sete da manhã do outro dia, ficava colando essas doze horas, dez horas, porque não tem ônibus que passe a noite inteira, entende? Sentava, dormia um pouco, e ia de novo. A comunidade acabou vendo os adesivos e me levando de volta pra aldeia pra conversar sobre o que estava acontecendo. Quando eu cheguei lá foi bem bonito, porque foi em São Miguel das Missões, tinha uma fogueira, tinha uma velha cozinhando pra mim, me esperando, sabe, como forma de carinho, e a gente conversou muito. Aí eu comecei a me aprofundar mais sobre as etnias que viviam no Sul. Porque é muito genérico - o ser índio. As pessoas não conseguem distinguir as coisas, as variáveis que têm, a parte étnica. A gente tinha que saber no primário [Ensino Fundamental] as etnias que têm aqui. Pelo que eu mapeei, umas oito etnias viveram aqui e não existem mais. Então eu comecei a me aprofundar e o trabalho mudou. Tinha diversos tipos de modelos, tinha o indiozinho com black power, que era o indígena quilombola; tinha o indiozinho com o capacete de mergulho, que era a poluição das águas, mas era uma vertente mais lúdica, depois eu vi que não queria mais fazer, tanto que eu não produzo mais essas imagens.

4 Documentário dirigido por Tiago Bortolini. Disponível em https://www.youtube.com/watch?$\mathrm{v}=2 \mathrm{P} 2 \mathrm{FsSwi8Zw}$ 
Comecei a ter relação com a comunidade. Lembro que fui à comunidade dar uma oficina de pintura para as crianças e o cacique falou: "Olha, é muito legal o que tu faz, mas não é importante agora pra nós." Perguntei: "E o que é importante?" E ele disse: "A construção de um banheiro. A gente não tem um banheiro." Aí eu construí um banheiro. Eu e um amigo. Ficou torto. Aí eu dizia: "Cacique, tá torto isso, sabe?" E ele olhava de longe, e eu acho que as mulheres diziam pra ele: "Não, não, diz que está reto pra ele continuar", e ele: "Não, tá muito bom." E aí a gente acabou fazendo um banheiro na aldeia Tumbatopã Dolami. Reflorestamos a aldeia com madeira para artesanato, então hoje eles estão fazendo artesanato. Essa aldeia da Zona Sul de Porto Alegre é uma aldeia muito pobre, e a última vez que fui lá foi quando Paulo Herkenhoff ${ }^{5}$ comprou os fios pro banheiro. Eu fiz o banheiro, mas não teve dinheiro pros fios. Eu acho que foi em 2012.

Depois disso eu comecei a dividir as coisas com a aldeia. Eu acho que com a boa ação a gente está preparando a comunidade para ser vulnerável. Eu vou te "dar", a palavra é muito forte, porque nada é de graça, a gente sabe. Tudo tem um preço, o dar tem um preço, de acostumar as pessoas a ficarem vulneráveis e a ficar pedindo, e a virar pedintes. Então eu sempre troco por trabalho. Por exemplo, entrou um trabalho agora, eu divido. Um faz uma parte, outro faz outra. Como o Laércio. O Laércio é parceiro há muitos anos, uma pessoa muito legal de conhecer, ele é vice-cacique e faz Licenciatura em História na UFRGS [Universidade Federal do Rio Grande do Sul]. Então ele carrega um peso muito grande porque não concorda com a História. Ele tem que escrever sobre aquilo em que ele não acredita. Eu tentei entrar na universidade e fiquei um mês, na UERGS [Universidade do Estado do Rio Grande do Sul], porque na UFRGS eu não passei porque tinha que desenhar. Eles mandaram desenhar o que não tinha sentido, eu desenhei outras coisas que eu queria, era desenho de modelo vivo, eu acho. Imagina pagar um curso preparatório pra desenho. Agora vai mudar, porque tiraram essa prova [Teste de Habilidade Específica - THE]. Eles demoraram trinta anos pra ver que Artes Plásticas é diferente de Artes Visuais. Aí eu fui pra UERGS mas não me acostumei, fiquei um mês ou dois, era muito confuso na sala de aula. Às vezes pegava esse bicho e deixava ali, aí a gente dava mil pensamentos pro bicho. Porque o bicho era assim e criava mil imaginações, e isso pra mim não fazia tanto sentido porque eu sou um cara da rua. O meu negócio é fazer alguma coisa provocativa, colar e pronto.

5 Curador e crítico de arte brasileiro. 


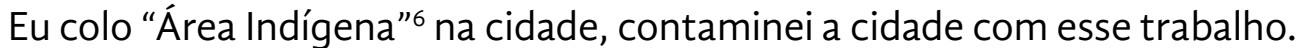
Porque a gente sabe, Porto Alegre é construída em cima de uma aldeia indígena, é rodeada por diversas aldeias; cada vez que a cidade cresce, a aldeia diminui, e a aldeia, consequentemente, é dependente da cidade porque o espaço é muito pequeno pra plantar, então os indígenas vêm pro Centro da cidade e povoam ali por um tempo, e eles voltam pra casa depois que vendem [o artesanato]. Só que o "Área Indígena" começou a ser colado na cidade e eles olharam e começaram a ficar embaixo. Alguns tiraram, outros pensaram que era um decreto municipal porque é uma placa. Um promotor pegou bem no "Área Indígena" e fez eu limpar no horário comercial, eu limpei com ele filmando.

Figura 3

Xadalu Tupã

Jakupé

Área indígena, s/d

Dimensões

variadas

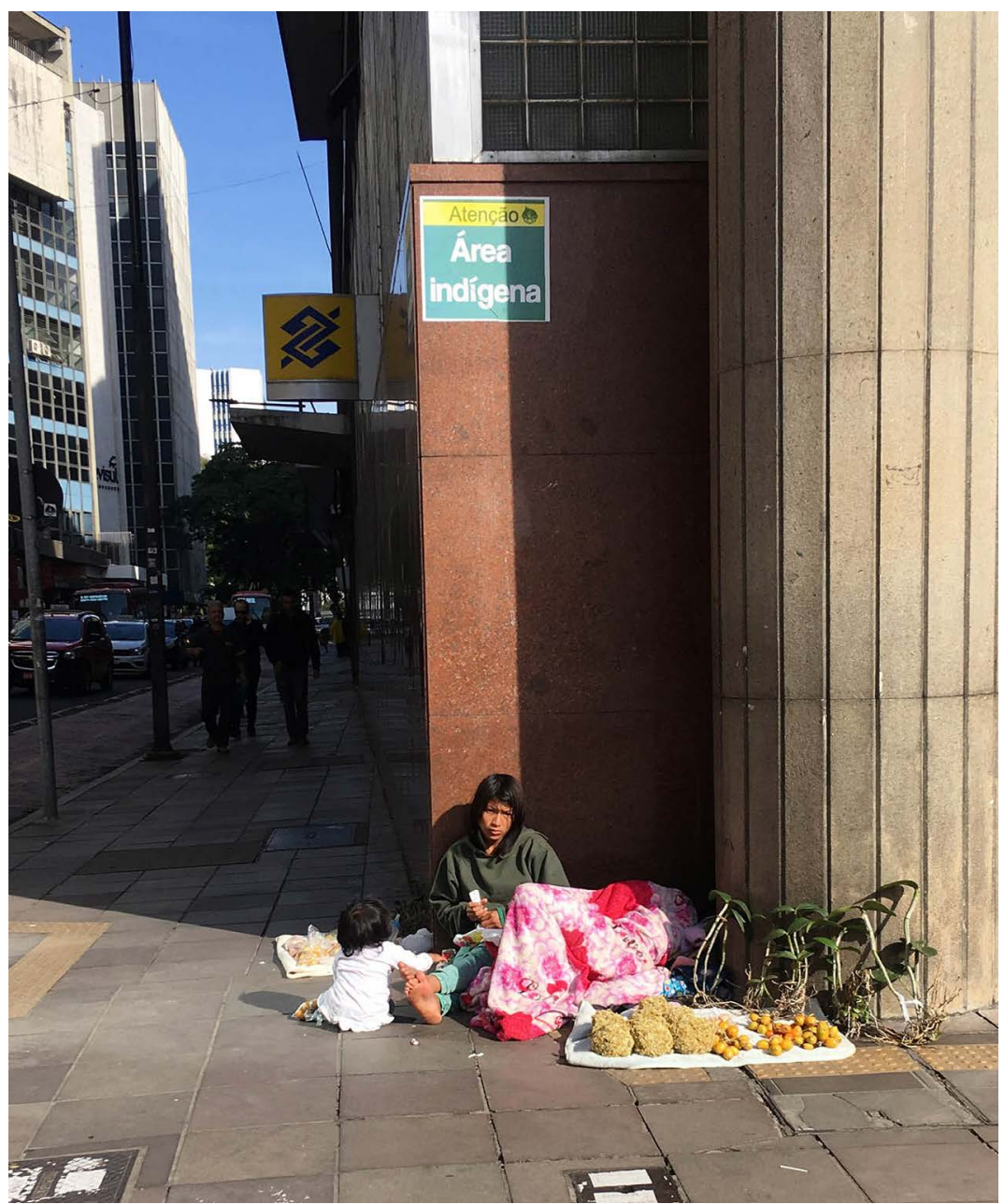

6 Cartazes ou adesivos em forma de placa de sinalização, instalados nos espaços da zona centra de Porto Alegre, RS, 2016. 
IA: Como é que as crianças, com as quais você está trabalhando nas comunidades, veem essa história da rua, da cidade, quando você chega e ensina nas aldeias. Você sente que isso cria uma outra visão, da relação do indígena com a cidade?

XTJ: Dentro da comunidade foi criado um ícone que é o Xadalu Tupã Jekupé. O pessoal respeita como um ícone, isso é bom e ruim. É bom porque tu vai ter acesso a histórias que uma pessoa da universidade não ia conseguir ter. Hoje a minha linha de trabalho, eu não digo de pesquisa, mas de interação dos fatos com história e a mitologia, é uma coisa muito profunda e quem analisa isso são os próprios sábios. Eles analisam o trabalho, eles falam que está muito profundo, que está bonito. E ao mesmo tempo a gente não quer que seja ícone, isso falando de coração mesmo. A ideia é incentivar a comunidade a não me admirar, mas a se empoderar também. Porque a gente sabe que a cultura guarani não tem a pintura como um elemento, a gente vê que está tendo uma mistura, eu vejo com muito cuidado, porque eu vejo a arte indígena como sendo as coisas de madeira, a pintura corporal, mas a pintura em tela, a pintura no tecido, já é uma outra coisa, já é uma mistura, uma miscigenação, e uma forma de mostrar e buscar a valorização da cultura, porque o empoderamento todo mundo que é, tem.

Eu acho que a arte indígena é feita pelo indígena, eu não consigo ainda ter isso bem claro porque eu fico pensando muito nessa mestiçagem de materiais em busca de um novo trabalho como sendo muito contemporâneo. Existe trabalho no Rio, em Roraima tem o Jaider e tem o Denilson. ${ }^{7}$ Eles são da aldeia, mas estão no contexto urbano. Então pra eles é muito natural ver uma instalação, mas eu acho que dentro da comunidade isso é muito precoce ainda, trabalhar com materiais, entender o que é uma exposição e entender o valor disso, porque o valor dentro da comunidade é um valor natural que se sabe que vale muito, que ninguém precisa falar nada, é a continuação da história, mas a absorção das instituições é bem precoce ainda.

Acho que a gente tem que policiar, principalmente os fotógrafos. Registram a comunidade, saem de lá fazendo exposições, e não retornam nada. Tem que retornar pra comunidade, mesmo que role ou não role grana. Porque lá não tem como eles saberem o que aconteceu, entendeu? Imagina, eu fui lá entregar o dinheiro de uma obra que foi vendida para a coleção Frances Reynolds. Não tem, no meu caso, o salvador da pátria, é tudo dividido, a gente

7 Artistas indígenas contemporâneos - Denilson Baniwa e Jaider Esbell. 
trabalha, divide o dinheiro e ponto. Não estou ajudando ninguém, estou só dando a parte deles. Eu fui levar a parte da foto de uma senhora. Eu conheço muito a pobreza, porque vivi nela, só que a miséria é algo muito absurdo, porque na pobreza tu ainda consegue ter interlocução de pedir, dialogar com o espaço, mas na miséria está isolado num lugar que não tem possibilidade alguma de buscar algo.

Aquela aldeia estava na miséria, eles estavam fragilizados, na beira da estra$\mathrm{da}$, entre a cerca de uma fazenda e os caminhões, morreu até uma pessoa atropelada por um caminhão. Todo mundo me conhece, quando eu pisei na aldeia foram correndo chamar o cacique. $E$ a velha nunca tinha visto tanto dinheiro, porque eu levo dinheiro na mão, quem dá o dinheiro sou eu e ponto. Eu demorei um dia viajando até lá. Um dia pra ir, um dia pra voltar. E aí eu coloco o dinheiro no chão, mostro para ela, explico o que aconteceu, eles não entendem muito. E ela pergunta o meu nome, meu nome de batismo, eu explico, ela diz que vai meditar um pouquinho no fogo e diz que depois tem umas coisas pra me dizer. Enquanto isso, eu fui conhecer a aldeia e estava lá com as crianças, e as crianças estavam muito vulneráveis.

Figura 4

Xadalu Tupã

Jekupé

Escola Onça, s/d.

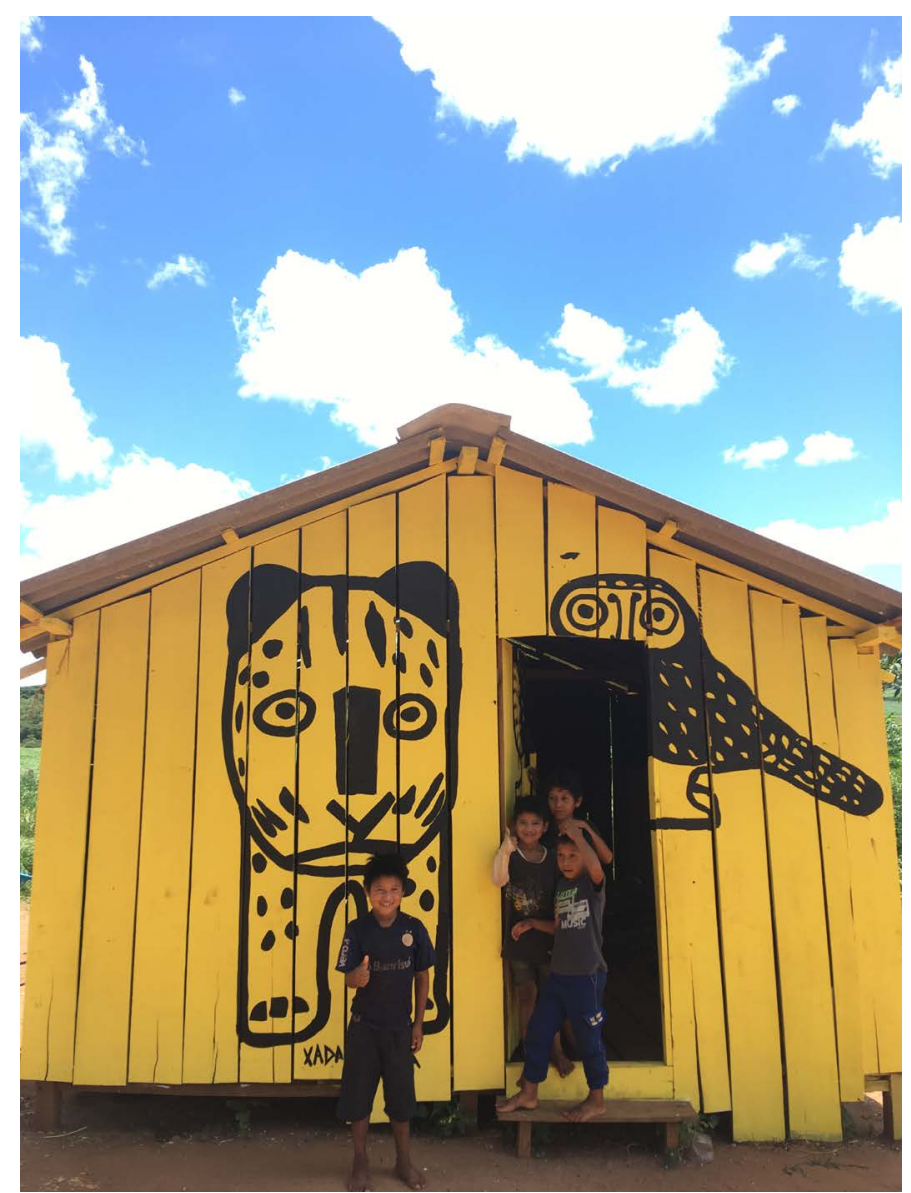


Eu consegui construir uma escola para eles darem aulas pra eles mesmos. Vou pintar essa escola, deve ser uma escola onça. Consegui as tintas com uma marca de tinta aqui do Sul, o diretor do Museu de Arte Contemporânea conseguiu dez cestas básicas que é o que eu precisava, e eu vou ver se arrumo os lanches porque são 77 pessoas. A gente doou uma cesta básica pra cada família - que são dez - e os lanches são pras crianças. Porque a comida é algo sério, sabe? E muitas pessoas que estavam lá não gostaram da minha presença. O que esse cara quer aqui? Ele vive viajando, ele estava em Paraty, no Rio de Janeiro, ele estava lá com os caciques que são muito reconhecidos... Isso eu imaginei quando eles olharam pra mim. Outros ficaram bem eufóricos porque eu estava lá e de alguma maneira ia fazer algo. Porque uma aldeia como aquela é muito longe, é uma aldeia em que eu não vou poder ir sempre, então eles sabem que vai ser uma coisa rápi$\mathrm{da}$, e eles acreditam que essa passagem pode ser boa.

IA: Qual é o nome dessa aldeia?

XTJ: Não tem nome, é uma aldeia que não tem nome. É na BR, na beira da estrada. Eu perguntei ao cacique: "Como é pra se concentrar aqui? Esse caminhão passando já está me incomodando, aqui não parece que é uma aldeia." Aí ele falou: "A gente se acostuma, e se as coisas são assim, são assim. Não tem força pra sair daqui agora, então a força é ficar aqui." Foi bem triste, eu saí de lá bem triste. Na hora de ir embora eles se reuniram e me acompanharam até a parada. Eu fui de ônibus. E ele pediu pra eu voltar.

IA: A gente vê o seu papel como o de um tradutor. Um tradutor da aldeia na cidade e da cidade na aldeia. Mas também tem isso que você está contando, quando você chega num lugar olham pra você como se não fosse desse lugar, depois você chega em outro lugar e também tá fora do outro lugar, não deve ser uma posição fácil.

XTJ: Ainda bem que eu tenho sensibilidade. Eu acho que é essa mistura de tudo, de saber usar aquilo que toca a gente. Mas aí eu fiquei triste no primeiro momento, e conversei com as instituições. Existem algumas instituições que são boas, vou dar exemplos: o Sesc é uma ótima instituição para trabalhar e conseguir levar algo para a comunidade, mas isso tem que partir do artista. $\mathrm{O}$ artista tem que ir conversar, já muda a história. $\mathrm{A}$ instituição diz: "Ah, vai conversar com a comunidade?", eu digo: "Claro, porque a gente está fazendo junto, sou só a extensão da comunidade." Se eu quisesse eu poderia dizer "vamos fazer", depois explicava pra comunidade e pronto. Mas acho que a gente tem que jogar essa responsabilidade 
para as instituições em que estamos trabalhando também, porque senão, no fim, quem vai sair perdendo é sempre o artista.

Então eu conversei com algumas instituições. Imagina, num telefonema ele conseguiu dez cestas básicas. O outro, num telefonema, conseguiu todas as tintas pra pintar a escola. Agora eu vou ver se consigo o pessoal do cinema para fazer um minidoc disso, pra mostrar à comunidade. Tem um trabalho que se chama "Casa de Reza", no qual eu recolho lonas dos acampamentos de beira de estrada, e escrevo as rezas dos indígenas. Um trabalho desse está até no MAR [Museu de Arte do Rio], naquela exposição Casa Carioca. ${ }^{8}$

Hoje eu vejo o peso do valor institucional, quando a gente consegue gestores parceiros, eu acho que o potencial para ajudar a causa muda. A gente começa a poder usar a estrutura que deveria ser usada e não é, pra colaborar com a comunidade. Acho que a gente saiu um pouco do foco, que era colar adesivo, e foi pro lado social.

TQ: Não, na verdade não. Percebemos, pelo que você nos conta, que existem pontos de contato com aqueles personagens da mitologia que são designados a levar mensagens de um mundo para outro, de fazer uma certa tradução de e para esses mundos, um lugar que você, de certa forma, ocupa. Eu acho importante você ter a consciência política desse papel.

XTJ: Ano passado eu fui batizado, no Rio de Janeiro. Aí no Rio existe o cara do mais alto escalão para batismo. É um Opygua. ${ }^{9}$. Pouquíssimos existem da cultura guarani. Ele tem 101 anos e é respeitadíssimo. Em todas as comunidades - Paraguai, Argentina - todo mundo o conhece, então, quando ele batiza alguém, e fala o nome é o nome. Não tem como ele se enganar. Um dia eu estava conversando com ele e ele falou: "Olha, no próximo tempo novo, nos ventos quentes e nos dias longos, tu tem que retornar pra gente saber de onde tu veio, como é que é o teu nome." Aí eu fiquei bem feliz, porque eu pensei que ia ganhar isso só quando eu estivesse bem velhinho. E ele falou que o momento era importante: "Tem coisas que poderiam ser feitas depois, mas a urgência manda agora."

8 Exposição Casa Carioca, Museu de Arte do Rio, curadoria de Marcelo Campos, curador chefe do MAR, e Joice Berth, 2020/2021.

9 Chefe religioso guarani. 
Aí eu voltei lá, e foram dias de rituais. E no final fiquei surpreso, porque esse senhor só sabia que eu era da comunidade, que eu vivia na comunidade, que eu tenho essa relação há muitos anos, então quando me falou o nome, ele acertou algo que era óbvio, mas não sabia, e a comunidade também não. Então meu nome é Tupã Jekupé. Aqui no Sul é raro, acho que aqui só conheci um Tupã em quinze anos.

Tupã vem da cidade do Oeste, que é a cidade dos trovões. Existem quatro cidades celestiais, uma do Nhamandú, que é do Sol, o pai das luzes. O Sol e a Lua são irmãos, um depende do outro. Eles vivem trabalhando, são uma parceria eterna entre o homem e a mulher, porque eles fazem o dia e a noite, eles não podem parar um minuto, eles são incansáveis. O Nhamandú é Leste, o Tupã é o Oeste. O Norte é o Jakairá, que é a bruma, a temperatura da terra. E a fumaça é um dos mais fortes, porque a fumaça é a única que consegue tocar no espírito. O espírito só é tocado pela fumaça. E ao sul, é um dos mais severos. A gente está tendo hoje o prazer de entrar em atrito com ele, que falou que não ia se envolver nas nossas guerras internas, que o mundo podia ser alagado, queimado, por Nhamandú, ou por Tupã. Ele falou que nunca ia se envolver, e acabou se envolvendo - é Karaí, o deus do tempo. Então hoje a gente está num atrito com essa coisa do tempo. As pessoas estão morrendo por causa do tempo, não conseguem esperar as coisas, querem sair. Essa foi a palestra que a gente deu, eu e o cacique, falamos do Karaí Retã, que é o deus do tempo. ${ }^{10}$ Ele é o deus das bonitas palavras, o cara da roda de fogueira.

Então eu venho do Oeste, que é um pessoal muito sério, brabo, mas que é leal. Um Tupã nunca vai trair. Quando fala Tupã eles sabem que é uma pessoa que vai brigar, acabar a amizade, mas não vai trair. Não vai ter algo cínico, vai ser algo bruto. O primeiro nome é de onde tu é. Tupã do Oeste, trovão, chuva, água; o segundo é o que tu faz ou o que tu é. Então, quando um guarani te disser o nome dele, ele vai te dizer dois, um tu sabe de onde ele veio, e outro tu sabe o que ele é. Por exemplo, Karaí Mirim. Karaí do vale do tempo, pessoa tranquila, calma, não é uma pessoa que vai ficar ansiosa. Mirim vai te dizer o que ele é, uma pessoa dócil, tranquila, faz amizade fácil. Tupã Jekupé. Meu segundo nome, Jekupé. Eles chamam o Jekupé de informante, polícia, visão. Então, quando um Jekupé está perto de um sábio, o sábio tem que ter muito cuidado com o que ele vai contar

10 Refere-se à palestra realizada on-line em maio de 2020 pela Fundação Iberê Camargo com o cacique-geral Mburuvixá Tenondé Cirilo sobre cosmovisão, tempo e natureza. 
pra um Jekupé. Porque eu nunca anotei nada na aldeia. Eu nunca precisei anotar nada, eu só escuto, e ponto. Ele vai me contar uma história de meia hora, eu vou sintetizar essa história e não tem volta, eu já sei.

Então um Jekupé sintetiza tudo muito rápido, e carrega dentro dele, vai em outro lugar e conta isso pra outra pessoa. A partir dessas trocas de informações, vai criar todo esse contexto. Então eu uso isso trazendo pra arte. Toda essa pesquisa que eu tenho [vira a câmera do computador para o lado de sua parede com muitos desenhos e anotações], e eu escrevo muito, quando os caciques vêm aqui eles se assustam. Porque eu fico me lembrando de tudo e vou escrevendo, depois eu começo a criar, demora muito para eu criar a obra. Só que a gente vive também com a venda. A gente tem que vender as obras, ajudar a comunidade. Isso às vezes me deixa um pouco ansioso, mas está indo muito bem, até agora. A gente está conseguindo fazer as coisas.

Mas sobre as crianças, hoje eu faço estudos à distância em licenciatura, em Educação Artística Indígena. Eu vou dar aula no ano que vem, nas aldeias, dar aula de arte. Porque eu já sei, a comunidade não está acostumada com pintura, com instalação, de alguma maneira mais formal. Eles podem fazer no caderno, explorar mais o desenho da aldeia, ganhar gosto disso. Porque a comunidade dificilmente vai ter um artista, porque se acredita que todos são fruto da arte. Então eles acabam buscando a formação acadêmica em outras áreas.

Rafaella Souza: A título de curiosidade, Tupã Jekupé é o seu nome sagrado? Quando é batizado recebe um nome sagrado?

XTJ: O nome sagrado é Tupã Jekupé.

TQ: E Xadalu?

XTJ: Eu já falava Xadalu quando eu tinha 9 anos, e nem era Xadalu com $X$, era Shadaloo, com SH, nome da organização do vilão do Street Fighter.

TQ: As histórias de cada nome são maravilhosas, cada um na verdade fala de um aspecto, não é?

XTJ: Isso. Quando eu falei "meu novo nome", ele disse: "Esse aí você já tinha quando nasceu." Ele não ficou espantado, porque a gente carrega os nossos nomes internos, desde que nasce. Ele falou assim: "Só te revelei, não tem nada de mais nisso." Mas ele estava bem feliz que isso aconteceu, 
que ele pôde fazer isso. E o jeito que é revelado o nome é um jeito bonito, sabe, é antes do primeiro raio de sol da manhã.

Quando eu estava na comunidade, ele desenhou pra mim e disse: "Quero te dar um conceito." Falou sobre a ótica vista na cosmovisão, foi muito legal. E depois, no outro dia, ele falou: "Tu tá pensando naquilo ainda, não é?" Fiquei pensando naquilo, porque é como ele vê os raios do sol, como ele forma a imagem, como se forma cor. Então ele falou: "Eu nunca pude falar isso com ninguém, nunca veio pintor aqui, nem quem desenhava", aí ele se arriscou a desenhar. Ele já queria fazer mil coisas, porque eu estava lá dando uma oficina de serigrafia pra comunidade vender as camisas. Depois, eu fiz uma segunda ação, e dei metade do valor pra comunidade, do valor do trabalho.

E eu fui muito feliz de ter um olhar dele sobre as Artes Visuais. Ele não sabia o que era Artes Visuais, isso eu acho o mais potente. Remete muito a algo que eu tava lendo sobre a origem da arte marginal, ela não é, não tem nada a ver com, pode até a gente colocar como pichação, como transgressão, do sistema. Mas tem a ver com fazer algo que tu não sabe que tá fazendo, mas está fazendo por instinto e porque gosta de fazer. E eu sentia aquilo ali marginal, de ser uma coisa pura, porque ele desenhou ali pra mim, ele quis mostrar o que ele via, e o jeito do ângulo. Parecia que ele estava vendo tudo assim [se debruça para a frente com o rosto virado para o chão], as coisas estavam assim [pousa uma mão na outra com a palma virada para cima], e aí ele falou que é assim quando tá lá em cima, é assim, não é assim [coloca a mão na frente dos olhos]. Se tem algo olhando pra elas, elas ficam assim [como se ele fosse as coisas, joga a cabeça para trás, voltada para o céu]. Então foi bem bonito, as passagens, me contou uns três contos. Esses contos eu estou trabalhando mais para o ano que vem.

IA: Agora sobre o trabalho que você faz dos "Seres Invisíveis", 11 foi depois do seu batismo ou antes?

XTJ: Acho que o trabalho depois do meu batismo é só aquele ali, que é um ritual sagrado. Ele está em processo ainda, ele é o cosmo astral guarani,

11 "Seres Invisíveis" (2016), trabalho que Xadalu realiza em diferentes versões, como lambes, adesivos e caixas luminosas - consiste numa série de imagens fotográficas de indígenas que ocupam as ruas do Centro de Porto Alegre para a venda de artesanato. Impressão fotográfica sobre chapa de raios- $X, 40 \mathrm{~cm} \times 30 \mathrm{~cm}$. 
é costura, colagem bordado, é algo celestial. Na real faltam cinco partes dele, ele vai fechar uma parede. São os planos astrais, guaranis, eu estou estudando, me aprofundando muito, só que nunca acaba. Na comunidade, quando tu chega a um certo grau de conhecimento, tu tem as chaves de acesso. Então vai poder perguntar, vai usar uma palavra-chave, que o cacique vai se sentir à vontade pra te contar daquilo.

É por isso que o pessoal da universidade vai e não sai quase nada, porque não tem a intimidade da chave do acesso, vai fazer perguntas normais "Olha, como é que tu vive?" Eu acho que depois de um tempo ele vai contar, vão ser contadas coisas, mas depende do grau de intimidade; são, às vezes, pequenas palavras.

IA: Você trabalha em equipe nos seus projetos ou desenvolve sozinho?

XTJ: Tudo sozinho, só levo a ideia lá e vejo se eles aprovam. Tudo eu. A segurança a comunidade dá, porque eles olham esteticamente. Esteticamente eles acham muito bom, e o conceito é o fruto de nossas conversas.

Sofia Skymma: Tem um vídeo onde você fala que o trabalho é consolidado na rua e depois exposto na galeria, em instituição de arte, onde ele tem um diálogo. Como se consolida um trabalho na rua? Como é que você sabe que um trabalho está consolidado na rua? É pela quantidade, é pelo volume? Qual a diferença prática dessa consolidação para esse diálogo?

XTJ: O que eu acho mais legal do artista urbano, que foge um pouco do artista tradicional da galeria, é que o artista urbano faz o trabalho não para curadores, ele faz pras pessoas, quem vai legitimar são as pessoas. $E$ tu vê a grande força do trabalho na cidade quando todo mundo começa a comentar sobre isso, entendendo ou não. Partindo desse ponto, eu acho que já é uma consolidação ter a opinião das pessoas que têm interação com aquele trabalho. Eu digo que um trabalho com repetição, quando chega a um grau de popularidade, como chegou a figura do indiozinho na cidade, ele se torna um grande hit. Imagina, eu colo isso há quinze anos, as pessoas não esquecem disso de maneira alguma. Tem adolescentes que falam: "Olha, eu vi o teu adesivo quando eu era pequeno, sabe?" A gente começa a juntar relatos de pessoas que mandam e-mail, que encontro na rua, quando eu estou colando.

Eu acho que a grande consolidação é quando eu estou colando na rua e passa um cara de carro e grita: "É isso daí, Xadalu!", bate palma, para o carro, desce e me abraça. Ou o morador de rua, que para de puxar a carroça ou le- 
vanta de onde está deitado, vai ali e conversa sobre isso comigo, sabe? "Bah, que loucura, eu vi isso na rua há muitos anos, não entendo o que é isso. $\mathrm{O}$ que é isso, me explica aí. Foi o índio que morreu aqui?" E a gente vai desdobrando as ideias. Eu acho que a consolidação do trabalho é quando ele entra em diálogo com as pessoas, e o artista consegue se aproximar e se apropriar também desse diálogo, eu acho que essa é a consolidação, diferente de uma instituição que já está lá. A instituição já é consolidada, então tudo o que vai lá pra dentro acaba sendo consolidado de alguma maneira.

Na rua é diferente, quem torna isso forte são as pessoas, porque a arte urbana tem contato com as pessoas e essa consolidação pode ser negativa ou positiva, eu acredito. Eu valorizo também o cara que não gosta, porque de alguma maneira ele não gosta e rasga, sabe. Mas eu acho que esse é o grande ponto, quando a cidade começa a falar sobre o teu trabalho. Se tu for na rua, aqui em Porto Alegre, e parar num centro e perguntar pra quinze pessoas se elas viram um indiozinho bege, não tem como não ver. As pessoas dizem "eu não entendo, mas eu sei que isso aí está por tudo", sabe? Do meu ponto de vista, como um artista urbano, não é? Sofia, tu pode questionar, pode dizer "não concordo".

SS: Eu concordo. Mas aí a própria consolidação da rua é um diálogo. Então, quando a instituição serve para diálogo é uma coisa, né, segue nessa linha. Eu sintetizei algo assim, você consolida na rua e aí leva para a instituição para que haja um diálogo sobre isso. A própria consolidação da rua é um diálogo, então eu fico pensando se isso não é uma estratégia crítica mesmo da institucionalidade do museu, da galeria, do que seja, porque já vem o negócio consolidado que já tem um diálogo por si, que já tem um retorno. Você já tem essa chegada e aquilo ali serve realmente como porta-voz, como um lugar para você fazer falar outros lugares a partir desse trabalho, a partir daquela instituição. Fico pensando se não é por aí. Porque tem esses dois lados, de consolidar e de diálogo, onde termina um e começa outro...

XTJ: Dentro do museu eu posso trabalhar com coisas que eu não conseguiria trabalhar na rua, por exemplo. Tudo é intelectual porque tudo vem de pensamentos e de conversas, mas acredito que aquela obra que eu mostrei agora há pouco não dá pra colar na rua, as pessoas não vão entender. $\mathrm{Na}$ rua é muito rápido, a rua não vai poder absorver aquilo ali, saber do plano astral, na rua é dez segundos pra mim, cinco segundos, olhou, impactou. Então acredito que na rua eu consigo ter uma parte bem agressiva e chocante como isso aqui, da menina com o colete à prova de balas, do milho, do sapo, da coruja, eu acho que isso funciona muito bem na rua. 
E depois, os desdobramentos desses trabalhos a gente consegue ver na galeria e no museu. Eu acho que a gente não tem como ganhar tudo, a gente tem que saber o que vale em cada espaço e isso só o tempo vai dar pro artista. A rua é massa, eu quero massa, eu quero a galera, dona de casa olhando, xingando, outras admirando, a polícia braba, imagina, todos os prefeitos da cidade me conhecem, até o governador. Os caras me conhecem, é o cara que suja a rua. Hoje em dia eu sei me posicionar.

Figura 5 Xadalu Tupã Jekupé Seres invisiveis (Lambe), s/d Foto: Moa Schneider

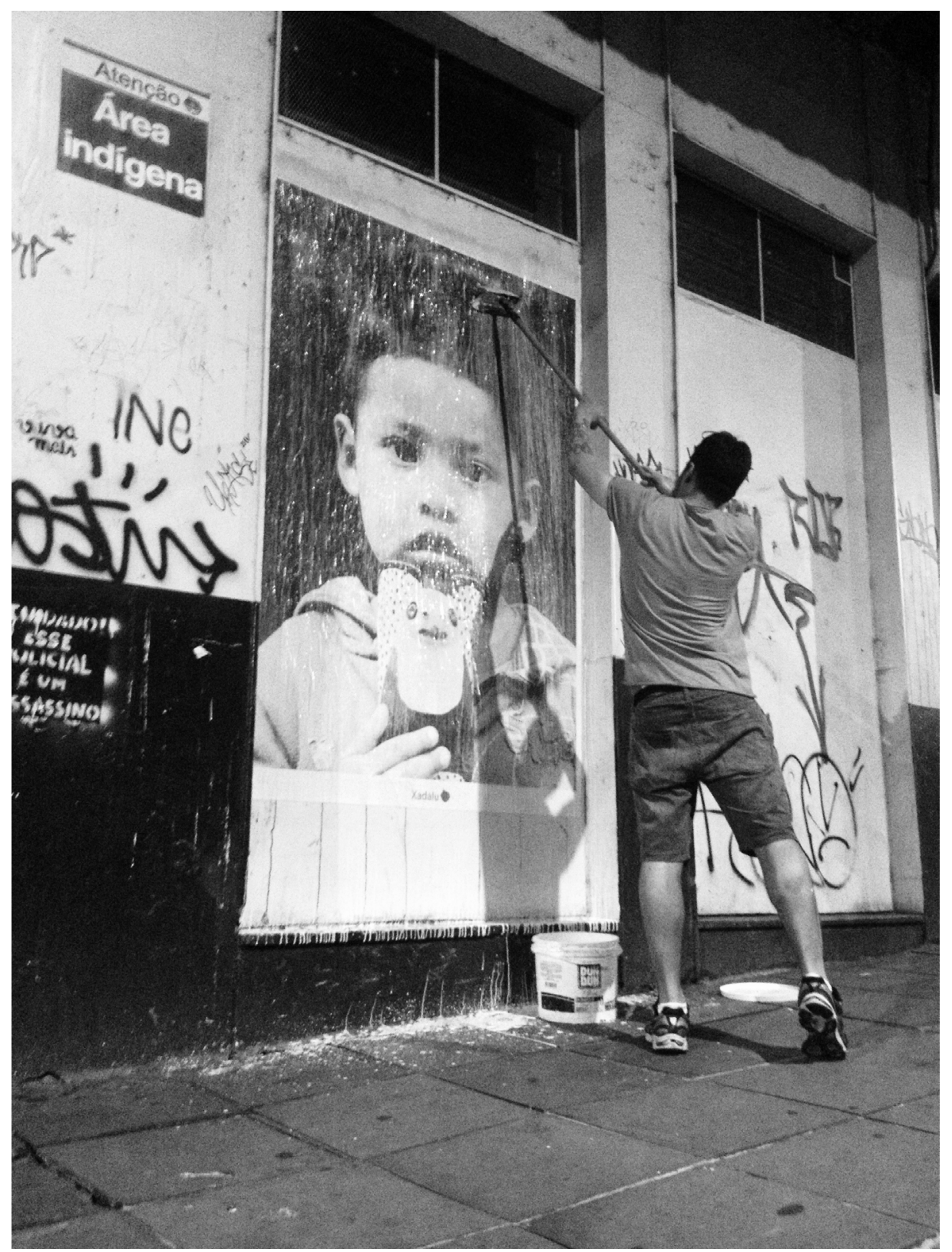


A arte urbana é coisa sagaz, explosão, imagem grande na rua, colorida, ou foto impactante, algo direto e reto, tem que ser muito rápido, pra pessoa pensar "por que é que a indiazinha está com um colete à prova de bala? O que houve?" Aí eles vão ler ali no colete Guarani Mbyá, ${ }^{12}$ sabe? Por que aquele milho grande está na rua? O que é que está acontecendo? Eu dificilmente uso frases nos trabalhos, porque eu tento buscar pela imagem, e hoje, de tanto fazer isso na cidade de Porto Alegre, as pessoas já sabem quando sou eu que estou fazendo, então acabam depois procurando no Instagram ou no Facebook. Eu uso pouco, mas eles acabam indo lá e o mais legal é que as pessoas conhecem mais o trabalho na rua do que na Internet. $\mathrm{Na}$ Internet tem bem poucos seguidores, eu acho que lá deve ter 7 mil e pouco, é muito pouco em relação às pessoas que conhecem mesmo da rua, de olhar ali. Eu acho que é isso.

TQ: Hoje tudo é muito pautado por essa circulação que existe nas redes e você consolida essa rede na malha urbana e ela parte daí para ir para os outros espaços e vai ultrapassando essas fronteiras fisicamente.

XTJ: Sim, e causa em todo mundo, porque ele vem dessa maneira de intimidar [refere-se ao promotor de justiça que o processou]. Eu entendo até o trabalho dele, porque ele é um cara assim, ponto. Podia ser eu, podia ser a Racquel, podia ser tu. Se qualquer um de nós todos que estivesse aqui tivesse feito isso ele ia encher o saco, então eu nem fico brabo com ele. Só que são pessoas, como o cacique falou, são pessoas que a gente vai ter que saber contornar para continuar o trabalho. Não adianta discutir lá. Tem uma coisa muito bonita na comunidade: "Mais importante do que quem fala, é quem está inspirado a escutar." Então não adianta discutir com esse tipo de pessoas. Antes do julgamento o cacique me ligou e falou: "Olha, contorna, nem perde tempo, já tá perdendo de ter que ir lá. Contorna. Tenta falar da palestra, não dá tempo pra parar pra essas coisas, vai perder muito tempo e podia ser tempo de produção. Cada coisa assim, contorna. Não vai ser a primeira nem a última, isso são as pedrinhas da caminhada."

Ele falou: "Nem perde teu tempo, se quiser eu posso ir." Aí no final a gente fez uma reunião e era melhor não ter ido, porque ele ia ficar brabo mesmo, né? Porque ele achou um absurdo a comunidade não poder ir para um lugar que era deles. Ele achou um absurdo, arqueologicamente a gente sabe que tem uma cidade ali embaixo. E tem mesmo. E por que não podemos ir lá?

12 Comunidade indígena Guarani Mbyá. 
IA: Você está falando sobre isso também, né?

XTJ: As fotos que imprimi gigantes e coloquei na rua, deles, as fotos dos velhos, o "Área Indígena", o artesanato, a arte que eu comecei a colar e os bichos. Eu acho que a partir dessas transformações, do indiozinho temático, a obra começa a ganhar um corpo, e hoje, além de tensionar a cidade, ela dialoga com as pessoas e, o mais importante, ela vai dialogar com as diferentes classes. Pra mim isso é o mais importante, é saber que a dona de casa, eu me inspiro muito na minha mãe, porque ela é faxineira, e ela nunca leu livros, e ela é negra, então, eu me inspiro muito nela porque ela é o povo, ela é a maioria que está na rua, que está andando. Eu me inspiro muito na imagem dela, dessa pessoa que sai de casa às cinco da manhã, volta às seis da tarde, que chega em casa, abre uma cerveja, liga ali o Raça Negra, sabe essa coisa de comunidade? Isso me inspira muito.

IA: O que ela acha do que você faz? Como é o olhar dela sobre o seu trabalho?

XTJ: Ela não entende. Não entende muito. Ela acha legal. A minha avó entende um pouco mais, mas a minha mãe, ela torce, "tomara que dê certo isso". Agora na pandemia o diretor da Bienal do Mercosul me mandou cestas básicas e eu mandei tudo pra casa, e ela ficou muito feliz. Ela não consegue entender, mas pra ela é surreal, imagina, o salário da minha mãe é 900 e poucos reais, com os descontos ela ganha 700 reais e ela sobrevive com isso e paga aluguel, imagina. Eu ajudo em casa, mas como é que eu vou explicar isso pra essa classe média aqui da UFRGS? Não tem como explicar. Eles vão achar que a gente é igual, a gente não é igual. Eu não sou igual a eles. Aí tu leva eles na comunidade, eles vão viver um dia de vivência e vão achar que é legal.

A comunidade está cheia de problemas que a gente tem que se juntar para ver. Eu só acredito que as pessoas vivem numa realidade aumentada, que a Internet proporciona isso e, em algum momento, vão ter que acordar. E o trabalho na rua abre essa questão, e eu foco principalmente na periferia e na aldeia. Tenho grandes amigos que são diretores, curadores, que eu gosto muito, gosto como se fossem da minha família, porque eu sou uma pessoa muito leal, me ajudaram no momento que eu mais precisei e não me ajudaram porque eu era um coitado, mas me ajudaram porque viram potencial, então isso eu acho bonito, isso eu valorizo. Então quando a gente começou a conversar onde chegou o cacique a gente falou: "Olha, não tem vítima aqui mais, não tem espaço pra isso, a gente 
tem que tornar de uma maneira que a gente possa trabalhar e fazer coisas acontecerem, não tem mais o pobrezinho, não tem tempo pra isso, senão a gente vai prosseguir vulnerável, sabe?"

Figura 6

Xadalu Tupã

Jekupé

Terra à vista, 2018

Pintura com pigmentos da aldeia

Pindó Mirim,

serigrafia, estêncil e costura de raízes

sob tecido

$300 \times 300 \mathrm{~cm}$

Foto:

Goethe Institut, Porto Alegre, RS

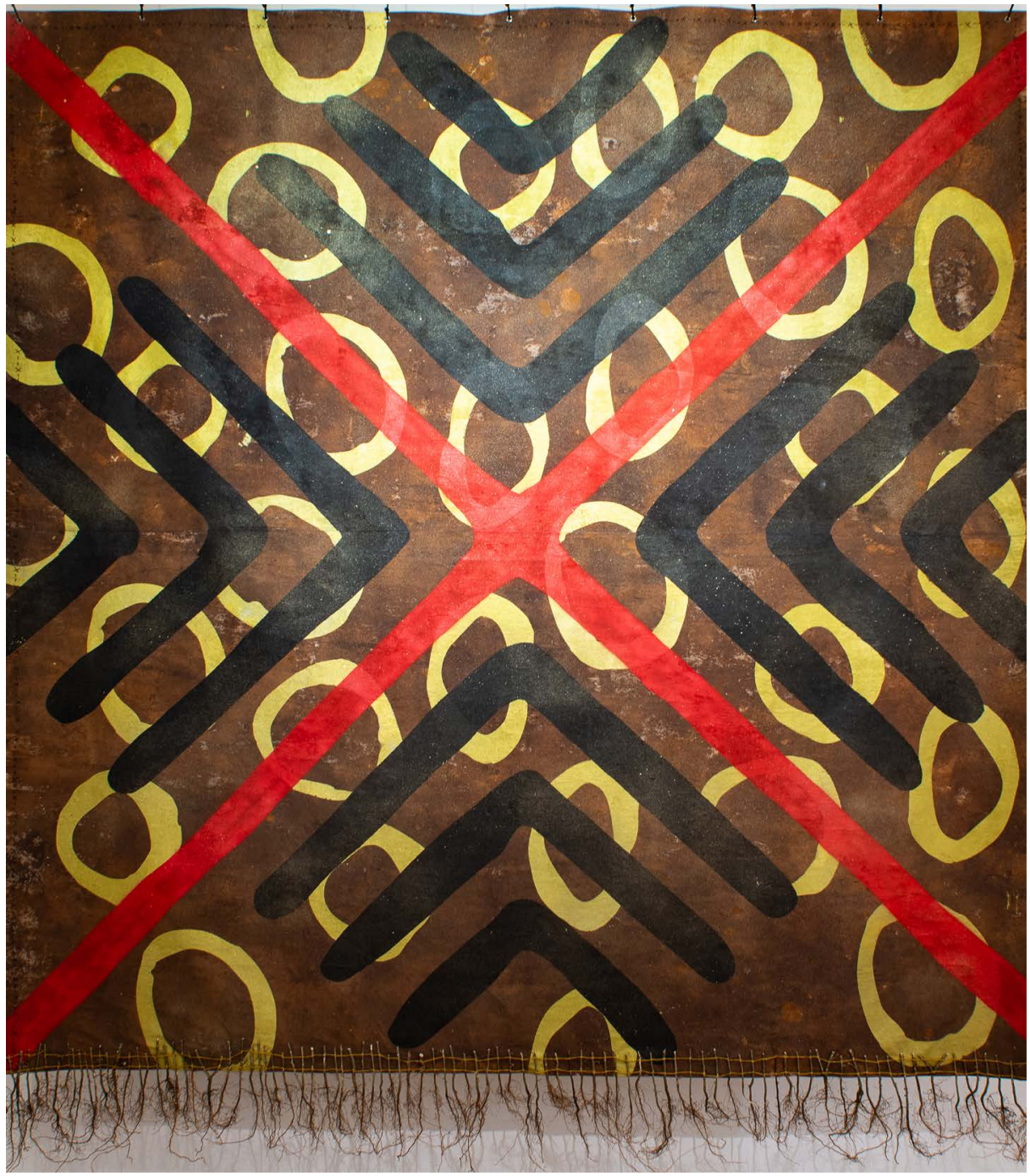

IA: E é bacana criar esse outro horizonte para a cidade. Uma cidade que tenha mais vozes. Xadalu, eu queria te perguntar sobre uma curiosidade técnica. Você trabalha muito com serigrafia e em algum lugar você disse que trabalha também com uns pigmentos naturais, só que eu vejo que você usa muitas cores fosforescentes. Você trabalha com pigmentos sintéticos ou à base de água? Porque eu estou vendo aí atrás, eu nem sei se são trabalhos seus, lindíssimos, a tinta à base de pigmentos. 
XTJ: Essa obra, a real dela tem $3 \mathrm{~m}$ x $3 \mathrm{~m}$, tem 9 metros quadrados, e ela estava na Alemanha, ${ }^{13}$ tem as raízes da aldeia e aqui [mostrando] é a terra da aldeia, e aí são três técnicas, são a terra da aldeia como pintura até passa pro outro lado do tecido -, serigrafia, estêncil e costura. Eu vou misturando. Eu gosto da terra da aldeia, do pigmento da terra, aquela lá da casinha tem terra da aldeia [mostrando], é gravura em metal.

Na rua é só lambe. Tentei no começo fazer umas instalações, até ficaram bastante tempo, mas na rua eu acho mais potente o lambe porque eu consigo andar rápido, eu levo num rolo, um balde, eu comprei um carrinho pequenininho, esses de feira, aí a gente soldou, eu levo um baldão de 20 litros, só que o problema é que quando a polícia pega eles pegam, o ano passado eu perdi uns carrinhos. Eles pegam o carrinho, e o pior, aqui no Sul a gente tem o extensor, aí dá pra colar os cartazes lá em cima, mas quando vai pra delegacia eles pegam. Eles pegam os adesivos, aí depois eles ficam olhando os adesivos porque os adesivos ficam bonitinhos, né.

TQ: Você escolhe o lugar para colar indiscriminadamente ou estrategicamente?

XTJ: Agora, com a pandemia, eu estou saindo pouco pra rua, mas normalmente a gente que trabalha com arte urbana está sempre de olho. A gente está sempre olhando os lugares, vendo. Tem dois jeitos: tem o jeito que é "nasceu praquilo", quando tu sai com um cartaz grande e vê que coube direitinho, foi um acaso esporádico, e tem também de vir no ateliê e acabar fazendo o trabalho pro local. Mas o que eu estava observando é que cada cidade tem uma construção peculiar, elas são diferentes, então a gente vai conseguir fazer uma leitura espacial e geográfica do local por vivência e a gente vai saber qual a dimensão do trabalho que mais se encaixa na cidade. Por exemplo, os trabalhos de $2 \mathrm{~m} \times 1 \mathrm{~m}$ eu sei que não vou conseguir colocar muitos porque não tem tanto espaço na cidade, porque eu coloco mais no Centro. Por exemplo, $40 \mathrm{~cm} \times 40 \mathrm{~cm}$ eu posso fazer milhares, porque eu vou conseguir colar por muitos lugares na cidade, porque tem espaço pra isso. Então a gente começa a ver, sabe, por determinadas zonas da cidade, onde a gente pode explorar mais, por exemplo, em áreas mais afastadas do Centro eu posso colocar esses trabalhos grandes, eu posso fazer bem mais e colocar mais, mas eu vou ter pouco contato de pessoas com esse trabalho. 
TQ: Menor visibilidade, né?

XTJ: Menor visibilidade de um problema que eu quero expor, então não faz muito sentido. Porque o que eu estou trabalhando ali nos trabalhos são problemas, né? "Seres Invisíveis", o "Área Indígena". Então não faz sentido eu colocar o "Área Indígena" aqui no bairro, que é a dez minutos do Centro, porque a comunidade não está aqui. Digamos que seria uma epopeia, sabe. Vou dar um exemplo. Quando eu comecei a fazer o "Área Indígena" - ele ficou pronto mesmo em 2012 -, eu só comecei a colar, eu acho, em 2015. E na época eu pensava ou "área" ou "terra", mas depois de várias imersões e interlocuções com os guaranis, que ficam no Centro da cidade, eu vi que "terra" as pessoas não iam levar a sério. O "terra" leva mais para um lado romântico. Depois, o Denilson Baniwa veio no Sul e viu o "Área Indígena". Ele fotografou e achou massa, aí meses depois ele criou o "Terra Indígena" que ele colou em São Paulo e foi muito legal.

Mas quando eu passei do "terra" para o "área", em 2012, já tinha esse problema porque o "terra" dentro do espaço da cidade se torna mais utópico. Colar um cartaz com a frase com o sentido da terra que a gente sabe o que é, está mais pro lado utópico, romântico, sonhador, e do lado área está mais contemporâneo. Ele trata do espaço do quadrado em que o guarani está e que as pessoas querem que ele saia - "Sai, sai, sai, não atrapalha a loja, sai, sai, sai, tira o teu artesanato, sai, bota pra lá". Está mais pela busca do espaço contemporâneo, que é na cidade, do que eu fazer algo escrito "terra". E aí, quando eu conversei isso com uma liderança, eu comentei do área/terra. Aí ele falou uma coisa: "Olha, o 'terra' está muito ligado a sonho." E aí eu consegui levar para o lado utópico porque, uma epopeia, imagina, destruir o Centro e voltar a habitar não existe, é uma epopeia. E aquilo me deu total segurança para colar o "área" mesmo.

E o primeiro foi o "área", porque eu comecei a trabalhar só espaço pequeno, o que a gente tem na cidade são pequenos espaços e essa luta pelos espaços e diferentes culturas, uma querendo engolir a outra, mas claro que a mais fraca sempre vai ser a mais afetada, ela vai tentar se impor. Quando a gente vê um guarani no Centro de Porto Alegre tentando vender um artesanato ele está se impondo, é um ato de resistência estar ali. Mas a gente sabe que a cultura do homem branco é majoritária, fisicamente e estruturalmente, e culturalmente, então é uma coisa que eu pensava muito. 
Num primeiro momento eu achei o máximo, criei um negócio "área", aí levei pra aldeia essa ideia do "terra" com "área". Eles nem sabiam o que ia acontecer, "mas o terra pra mim tem a ver com o sonho, e o área (ele nem sabia o que era área, né), tu tá falando que é pequeno espaço, disputa, cidade", ele não quis opinar, ele só não achou legal "aldeia". Nada a ver com aldeia, já foi, não é mais. E a partir daquela conversa eu fiquei mais convicto, e o primeiro respaldo que eu tive foi da própria comunidade. ${ }^{14}$ Aí entra a parte da legitimação, a comunidade legitimou a obra do "Área Indígena" nos espaços do Centro, até no portfólio eu coloquei várias fotos de indígenas ocupando o Centro com o "Área Indígena", e eles pedindo pra colar mais "ah, cola mais pra lá, pra gente poder chegar mais pra lá".

TQ: É, porque é uma delimitação de território na verdade, você delimita um território.

XTJ: Teve uma grande parte que odiou tanto que quando saiu na Globo daqui (a matéria no site não tanto, algumas pessoas comentaram), mas no Facebook, a gente vê no que as pessoas acreditam, as pessoas mostraram o verdadeiro ódio delas. $E$ na época até imprimi, levei para a aldeia esses comentários, porque o jornal tem grande alcance aqui, o Zero Hora, a RBS, em que falavam: "Ah, se eu puder eu cuspo nessa galera, que bonito de chutar esses artesanatos, tem que prender esse cara aí de uma vez, antes que ele..." Mas eram muitos e isso me deixou mais com vontade de fazer, porque se teu inimigo está te desafiando é bom isso, ele está com um pouco de medo também. E é melhor inimigos assim do que os velados, que a gente não vê e vai saber só depois que levou a punhalada. Então o "Área Indígena" foi uma baita experiência, que colo até hoje e vou colar sempre. A ideia de numerar o "Área Indígena" nem existe porque, na primeira noite, no primeiro final de semana, a gente colou mil, $50 \mathrm{~cm} \times 50 \mathrm{~cm}$, o lambe. Uma galera se juntou, não foi sozinho, foi um monte.

IA: Quando você sai pra colocar é sempre com uma galera?

XTJ: Isso! É a galera que gosta de mim. A galera que eu tenho contato mesmo é da pichação, então é uma galera bem mais radical. Foi muito goiabada pra eles, foi muito tranquilo, sabe? Falei pra eles, porque eles gostam de escalar, vamos colocar um pouquinho acima do olho das pessoas

14 Comunidade indígena Mbya Guarani. 
porque elas vão ter que se erguer para olhar, não coloca acima, elas vão ver que aquilo ali é uma coisa que está sendo sinalizada. Porque tem essa coisa, a gente não tem essa atenção, mas as placas das ruas com os nomes dos generais, elas sempre são acima, a gente tem que erguer a cabeça. Até os museus, quando a gente vai em alguns museus olha aquela magnitude e eu achei interessante colocar a magnitude do ato da colagem trazendo a história das nossas comunidades que estão à beira de Porto Alegre pras pessoas na cidade. Claro, tem pessoas que rasgaram só o indígena, sabe, o "área" um monte rasgou, e saiu no jornal.

Depois começaram a aparecer os outros trabalhos - "Seres Invisíveis", "Forma Guarani" -, depois teve os cartazes dos velhos que eu fotografei, as principais lideranças aqui do Sul. Eu os fotografei e fiz os cartazes de guerra muito inspirado no construtivismo russo. Esses cartazes eram ou eles com a enxada assim, ou a mulher com o bastão do ritual. E eu impregnei a cidade colando e foi impactante, porque os indígenas que vinham ao Centro viam os heróis deles nas paredes, se tornando algo público.

O Luciano Migliaccio, ${ }^{15}$ que foi do MASP [Museu de Arte de São Paulo], quis que eu ocupasse o salão da FAUSP [Faculdade de Arquitetura e Urbanismo da Universidade de São Paulo] do Artigas. ${ }^{16}$ Aí a gente fez as fotos - são três - três lideranças, dois homens e uma mulher. Nessas fotos o grafismo é relacionado ao cosmos de cada um, e a posição corporal, que eu estudei muito, dizia muito da pessoa. Então o Sr. Dionísio é da palavra, ele era uma liderança, ele está com o dedo para cima; o outro, que é o Sr. Mariano, era um agricultor, ele é a prova de que o indígena não era vagabundo, ele trabalha com a terra, dono da terra, então ele está com a enxada; e a senhora, que é a Sra. Laurinda, é uma anciã muito famosa aqui, conhecida. Eu fiz uma roupa de ritual para ela, e ela tirou foto com um bastão no peito, um bastão mitológico, que é isso aqui [mostra o bastão]. Esses bastões alinham nosso corpo que está desalinhado. Ela tirou as fotos, depois teve todo um trabalho de grafismo e daquela coisa de ser imponente no espaço, e eu fiz três fotocópias dessas imagens, com o recurso da FAUSP, e a foto tinha, eu acredito, $12 \mathrm{~m} \times 5 \mathrm{~m}$.

15 Professor doutor do Departamento de História da Arquitetura e Estética do Projeto da Faculdade de Arquitetura e Urbanismo, da Universidade de São Paulo.

16 Edifício Vilanova Artigas, FAUSP. 
Figura 7

Xadalu Tupã

Jekupé

Guardiões do

tempo, s/d

Cartazes com

$1200 \mathrm{~cm} \times 500 \mathrm{~cm}$

FAUSP - Faculda-

de de Arquitetura

e Urbanismo da

Universidade de

São Paulo

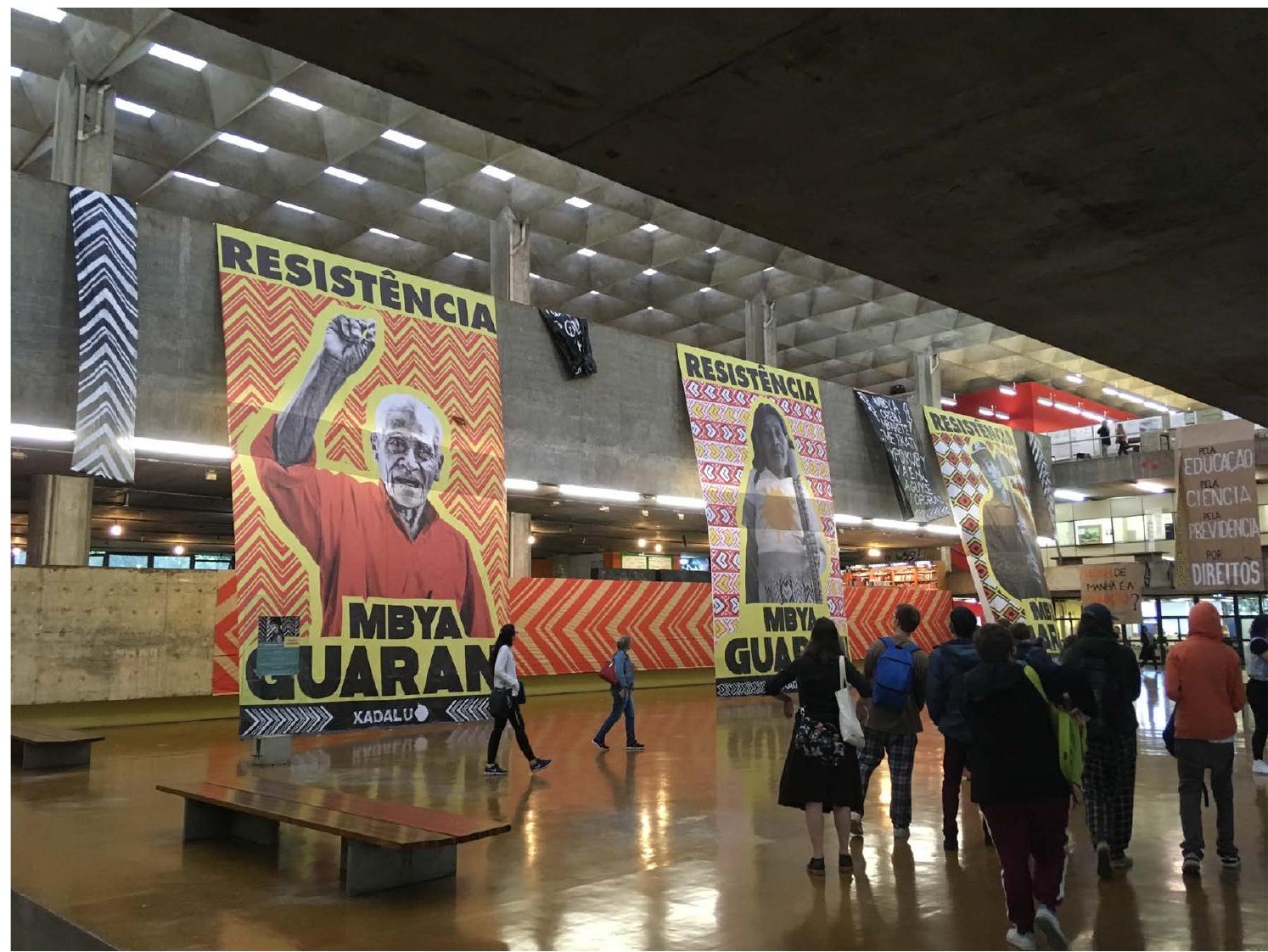

Ela ocupou todo o Salão Caramelo. As pessoas parecem uma formiga perto da foto. Quando começou a desenrolar as bandeiras tinha um indígena que nunca tinha viajado de avião, ele foi comigo, e um deles era o vô dele, e ele começou a tremer, sabe, os nossos heróis ganharam algo verdadeiro, do tamanho deles. Depois essas imagens reverberaram por todas as aldeias aqui do Sul, eles não entenderam o que estava acontecendo porque eu não contei pra ninguém, e principalmente na Argentina. Na Argentina eles são muito orgulhosos, fizeram camisetas das fotos, eles mesmos. No Instagram, os da Argentina me seguem, eles conversam bastante, mandam recado, então essa série foi muito importante e era uma série que eu tinha que dar sequência. Porque a reclamação deles é que a gente tinha que saber quem eram os heróis que mataram muita gente aqui e ninguém sabia os heróis da nossa cultura guarani. Ele falou mais: "Dione, tu tem o poder de ter essa interlocução com os brancos e tinha que aproveitar isso, fazer um livro contando a história de cada um e esse livro ia ser usado em todas as escolas guaranis." Então num primeiro momento eu tinha pensado nisso, mas depois eu acabei sendo engolido por outros trabalhos, mas ficou essa série pra um dia... 
Aí eu fiz algo parecido com o Cacique Cirilo, que é bem conhecido por sonhar com os lugares e retomar os lugares, ele participou de três retomadas bem importantes no Sul, e essas retomadas viraram áreas indígenas de volta. Então eu fiz uma bandeira para ele, na exposição que eu fiz no começo do ano no Museu de Arte Contemporânea aqui do Sul, que seguiu o mesmo padrão, só que horizontal. A bandeira dizia assim "Somos irredutíveis". Ele gostou muito e agora a bandeira ia viajar pro Rio para o Museu Nacional de Belas Artes, mas ele proibiu, ele quer botar na escola dele, então a gente vai ter que imprimir outra.

IA: Eu não entendi. Você explicou que ela era horizontal, como assim?

XTJ: As outras são verticais e expressam muita força. Mas pra mim no horizontal vai além. "Somos irredutíveis", e isso foi um pedido dele. Ele disse assim "Isso expressa muito as divindades [referindo-se às fotos dos três líderes]. Eu sou um cara mais guerreiro da terra, então eu queria que as coisas fossem mais horizontais, porque isso pra mim faz muito sentido, a expansão é assim."

IA: Qual foi o formato que você fez?

XTJ $5 \mathrm{~m}$ x 13m, é grande! E essa obra ficava em cima de uma televisão e na TV tinha espancamentos, mortes e esquartejamentos de indígenas pela retomada de terras. Tinha cena de sangue, o fazendeiro matando o indígena, e tinha cantos, existe um canto. O nome da exposição era "A invasão colonial YVY OPATA, a terra vai acabar". Quando começou a terra a acabar mesmo, na invasão, uma velha cantou uma música, que é a música do final, sabe, do final do tempo. Eu tinha uma gravação dessa música de 1979. Aparecia esse vídeo e tinha essa música, não tinha o som do vídeo, tinha o som da música. Aí diversas pessoas foram lá e tentaram retirar a obra da exposição, e eu fui totalmente contra, porque o que está acontecendo ali é o que está acontecendo nas aldeias. Não é pra tirar.

IA: Mas você diz pessoas da instituição, que quiseram tirar a obra?

XTJ Visitantes. Nossa, eu recebi diversos e-mails pra tirar. "Olha, tu não achou que ficou muito forte?" Eu falei que forte é a maneira como a gente vive, que a gente está, isso que é forte. Eu queria que quando as pessoas vissem aquilo elas sentissem raiva do que está acontecendo, do que acontece e a gente não vê, e a comunidade gostou da obra. Teve uma outra obra que chamou muita atenção na qual existia uma sala em que 39 indígenas jogavam Free Fire, que é aquele jogo de arminha. Eles se encontram 
Figura 8 Xadalu Tupã

Jekupé

Invasão colonial meu corpo nosso território, 2019
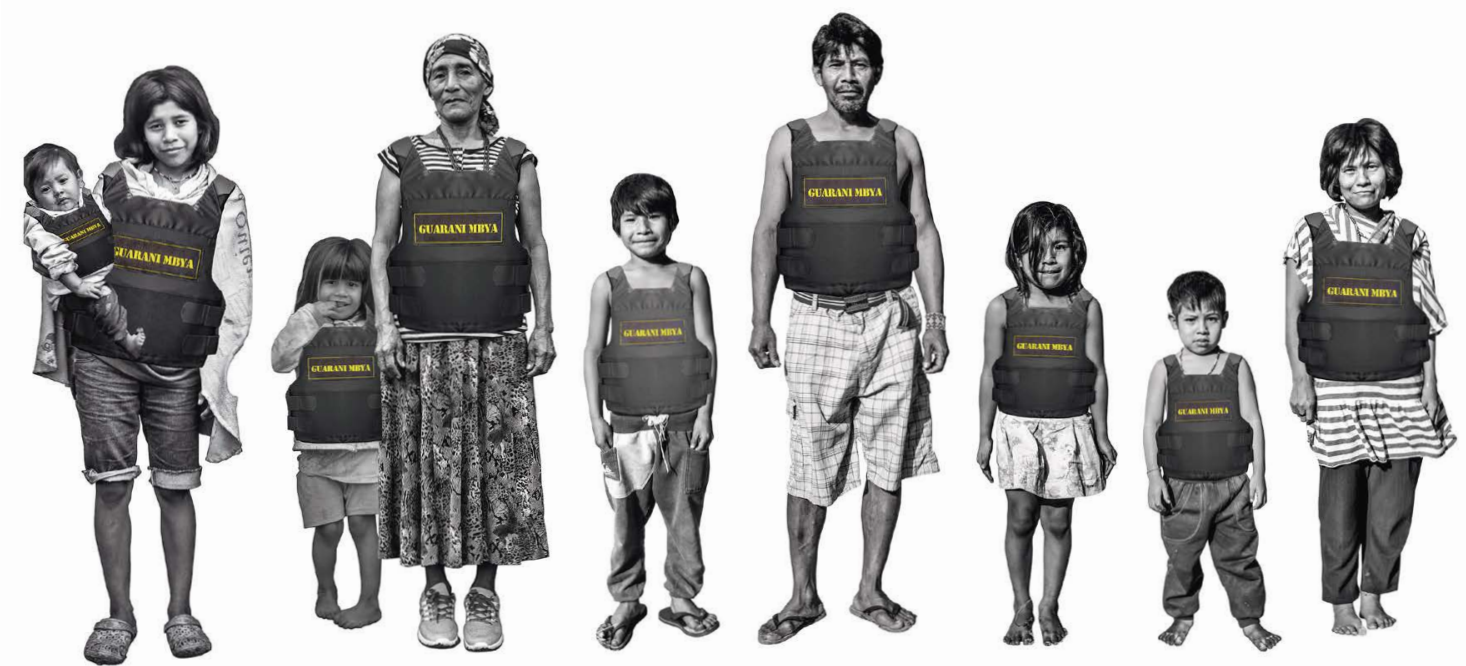

todos os dias umas oito horas da noite, entre umas quinze aldeias, na Internet pra jogar um jogo que é todo em guarani. Era uma televisão passando, eu gravei tudo porque eu sou o único mestiço, que eles falam, "no esquema". Então tu fala jogando, "ah, vem pra cá, vai pra ali”, tudo em guarani, os personagens deles, indígenas, com pena, com arma. Se isso é uma invasão colonial não sei, a tecnologia dentro da aldeia de uma maneira que transcende, porque eles se encontram todos os dias, tem campeonato disso que vale grana, só guarani.

Eu fiz o trabalho e botei uma arapuca ${ }^{17}$ gigante. Era uma arapuca gigante com uma televisão dentro e rolando esse jogo. Foi a obra que o Cacique mais gostou, ele falou: "Isso reflete a realidade bruta e absurda que a gente vive na aldeia com esse videogame agora. Olha, o videogame dentro da comunidade é uma arma que dispara a qualquer momento, mas a televisão é fácil, eu vou lá e desligo, vamos deixar a TV. Um telefone o cara bota no bolso, entra no mato e só volta no outro dia." A gente deu uma palestra juntos, lotou o museu, levamos toda a comunidade, e ele só quer falar nessa obra, ficou encasquetado na obra do videogame. Ele falou: "Esse é um problema de agora." Ele encasquetou nisso porque era muito genial, e era legal eu botar isso na aldeia, e ele falou pras pessoas passarem lá na comu-

17 Do tupi-guarani, "ara" = guirá, ave; "puca" = rebentar, estourar. Armadilha feita de paus com formato piramidal, destinada a pegar vivos aves, pequenos mamíferos e outros animais de caça. 
nidade e verem como a gente foi pego na própria armadilha. Foi um trabaIho que os brancos não acharam tão legal, sabe? Não entenderam muito.

Mas toda a comunidade gostou, as lideranças falaram que queriam que eu fizesse um vídeo explicando isso pra mostrar na escolinha. E aí, claro, nessa exposição teve diversas obras que foram bem fortes, foi uma exposição produzida por bastante tempo e depois foi legal porque teve esse contato da comunidade com as pessoas que visitavam o museu e esses diversos problemas, de não concordarem com o que estava ali, digo, os brancos, né.

IA: Agora, quando tem uma discussão sobre as obras, é uma discussão do público que vai na exposição, não só da comunidade, mas o público da cidade, e nessas discussões as pessoas conversam umas com as outras também.

XTJ Eu sou um cara da periferia, então as pessoas me veem assim e pronto. Claro, tem os sem noção que pensam que eu fiz universidade, sem noção que eu digo da própria universidade, do próprio sistema de arte. Quando tem essas interlocuções eu acho genial, porque quando tem uma exposição minha vai uma galera diferente, entendeu? Vai o pessoal de coletivo, o indígena já leva outra galera junto. Os antropólogos são quem gosta, sabe, tem os desinformados porque sabem que tem uma exposição e na hora vão lá e não gostam e vão embora, saem no meio da fala. Mas eu acho que cada artista tem um tipo de público ainda mais se tem um grau de reconhecimento. Eu sou um artista muito local, as pessoas todas me conhecem, vai o pessoal da minha periferia, vai o pessoal da pichação, alguma coisa do grafite, que são amigos de longa data, vai o movimento negro, alguma coisa do movimento feminista, vai juntando. Pessoas da faculdade vão poucas, não gostam, não vão, já se criou essa rixa, que as artes têm, e eu não dou bola. Mas vão pessoas importantes; por exemplo, o diretor do museu que apoia a comunidade, vai a galera que está junto.

Então as coisas são complexas, mas normalmente na minha exposição o público que vai é um público que gosta da causa. Gosta da arte urbana e tem também pessoas que são da academia e vão, mas são pouquíssimas. Tem muita mãe que leva filho, crianças. Bastante criança, muita criança, então eu acho isso legal, porque eles vão lá e se soltam, correm, me abraçam. E já ocorreu muitas vezes de crianças que estão fazendo arte porque viram eu fazer arte na rua. Tem até um artista mirim, que a gente chama, que ela já está com 9 anos, ela cola os adesivos desde os 6, por ver o indiozinho, ela cola um coração. Ela cola, ela tem rede social, ela faz a função dela ali, que é colar os coraçõezinhos na rua. Isso eu acho enriquecedor. 
SS: Eu tenho uma pergunta sobre essa estratégia de síntese e de decodificação pela palavra, você não usa isso pra dar o nome dos trabalhos, como na série "Seres Invisíveis", e aí eu fiquei pensando sobre isso e o que você falou sobre a cidade e a cidade embaixo da cidade, se não me engano era de Canoas, não era? E as fotografias dos senhores que você falou agora, eu queria que você falasse de um trabalho, que eu fiquei muito encantada, que é o "Arqueologia do Presente".

XTJ: As coisas vão mudando e é legal quando elas mudam pra melhor, quando não é, a gente vê que tem que mudar de novo. Num primeiro momento eu achava "Seres Invisíveis", uma baita sacada, porque a galera acaba absorvendo, mas depois eu comecei a entrar num âmbito de que a gente precisa valorizar a língua da nossa cultura. As obras vão mudando. Agora a gente entrou numa fase que eu acho que vai até o final, não vou mudar isso. Por exemplo, "Invasão Colonial, YVY OPATA" - que quer dizer "A Terra vai acabar", então vai ter sempre essa ligação da palavra guarani com o português porque eu acho muito importante as pessoas terem acesso pelo menos a algumas coisas e saberem que existem. No "Arqueologia do Presente", eu vou botar nas séries, as escritas nas obras, tudo em guarani.

No "Arqueologia do Presente", eu tive uma ideia. Eu via as crianças nas ruas quando vão acompanhar as mães, o que faz parte da cultura guarani, e isso é certo que faz parte, elas vão e pronto. A criança ali no ambiente urbano acaba... a gente não vê, mas ela acaba numa gestação de um ser marginal, porque ela vai aprender tudo o que não presta ali na rua, ela vai ver, porque ver também é aprender, né? Ela vai ver o cara que sacaneia, ela vai ver, porque na real ninguém queria estar ali, não é legal estar na cidade. Então a gestação daqueles dias em que a criança vai estar ali na rua é estar se tornando um ser marginal. Então eu acho que quando ela chega na adolescência ela tem esse nascimento marginal, porque ela já vai começar a transitar pela rua, leva o artesanato pra lá, pra cá, então eu vi isso com muita sensibilidade e preocupação, de até quando vai acontecer isso e de como isso vai ser, porque sempre tem um depois, enquanto tu estiver habitando a rua, como a comunidade está fazendo é sempre uma preocupação, o que é que vem depois?

O que vai acontecer com esse cara que já está inserido no sistema marginal, porque estar na rua à margem é estar no sistema marginal. Viver de esmola é estar no sistema marginal. E eu começava a ver que as pessoas não entendiam o que a comunidade falava porque a comunidade fala muito pouco o português quando está no Centro, fala guarani só. "Quanto é o 
bichinho?" Vai dizer só "cinco", cinco, quanto? A pessoa fala e só responde "cinco", é tipo assim "não fala a língua mesmo". Então a pessoa nem se dá o trabalho de querer entender, sabe. Antes de perguntar quanto é o bichinho "bom dia, tudo bom? Tudo." Claro, eu não vou dar bom dia, eu cumprimento na língua, eu falo médio guarani. E as pessoas não querem isso, elas só querem quanto é que tá... O bichinho é bonito, sabe, não querem saber o que é o bichinho, o bichinho tem uma história mitológica por trás. Se soubesse a metade da história do bichinho...

Aí eu comecei a ver esse contraste, ficava sentado a tarde inteira com eles, e quando eu vou é sempre uma alegria, porque eles querem conversar, querem saber como é que está a outra comunidade e eu mostro foto da comunidade. Fiquei alguns meses ali fazendo esse trabalho, que foi pago pelo Sesc na época. E aí, o trabalho de imersão, para fazer "Seres Invisíveis". Depois, "Arqueologia do Presente" foi o desdobramento do "Seres Invisíveis". Eu via que não entendiam a língua, não entendem o que está acontecendo e estão sendo marginalizados. Um dia, eles estavam embaixo de uma marquise, estava até chovendo e eles estavam centrados, embaixo de uma pichação. Aí eu tirei foto, e expliquei: "Sabem o que é isso? Pichação." Não entenderam e disseram: "Se tu diz que é legal, é legal." Eu disse: "Isso é uma arte que as pessoas fazem para ter visibilidade pra protestar, pra demarcar territórios, coisas." E ficou o assunto.

Aí eu voltei pro ateliê e fiquei muitas noites sem dormir pensando nisso. E aí um dia eu conversei com um pichador de uma gangue muito antiga eles chamam de gangue -, muito amigo meu, e disse: "Imagina se a gente ensinasse a pichação na aldeia, e a gente fizesse um painel de pichação guarani dentro do museu." E ele: "Não, não, isso aí está fora do que eu estou pensando, isso aí é outra coisa, e nem eles vão entender isso lá." Aí a primeira coisa era pichar nas ruas em guarani, a gente fez até algumas coisas, mas eu achei que isso não estava sendo forte. Eu acho que forte é fazer dentro de uma instituição porrada e as pessoas entrarem lá e não conseguirem ler o troço, porque é pichação e porque é guarani. Então, quando veio um grupo de indígenas para Porto Alegre, eu juntei os pichadores com os guaranis e a gente desenvolveu algumas coisas juntos e depois eu dei uma oficina de pichação na aldeia. Foi muito massa! Porque eles nunca tinham ouvido falar na palavra pichação.

Tem que pedir pra comunidade pra dar a oficina, não é chegar e dar. "Mas tu quer dar uma oficina de pichação?" "Claro, imagina só, quando for fazer protesto, tu bota nas faixas em pichação." Ele: "Não, não vou botar porque 
ninguém vai entender, ninguém entende." Eu falei que eu queria fazer o trabalho que a gente pode fazer no museu. Aí ele chamou a comunidade e falou: "Hoje de noite vai ter oficina de pichação." Eu falei que pichação é feita na noite, é melhor fazer na noite. Aí a gente fez a oficina de pichação em guarani e foi legal, eles usaram spray, usaram tinta de rolinho, e eu expliquei que rolinho é mais legal, tem baixo custo, aí a gente saiu pra pichar, eles ficaram com medo. Que merda, a gente tá pichando o que é certo e vamos ser presos ainda.

\section{IA: Aonde vocês foram?}

XTJ: A gente pichou em Porto Alegre. E eles falaram: "A gente tá pichando a verdade e vai ser preso. É, vai ser tudo preso." Depois eu comecei a entrar fundo no trabalho. Eu dei um tempo de tudo e comecei a trabalhar. E tinha um filme chamado Martírio, ${ }^{18}$ e eu achava legal falar uma verdade que as pessoas não entendessem, mas que fosse verdade. Sabe, eu estou falando a minha verdade que tu não está entendendo, que é em outra língua, mas é a verdade. Tu vai poder pensar qualquer coisa, mas não vai poder pensar que é mentira. Vai pensar qualquer coisa, mas o fato é que a palavra verdadeira torna aquilo verdade e é uma obra verdadeira e ponto.

E comecei a pesquisar vídeos de relatos de violência dos brancos fazendeiros na ocupação de terras porque a pichação vê muito isso do território. E aí eu cheguei num vídeo que a tradução é assim: "O homem branco é muito violento, destruiu toda a minha família", e ela vai contando como é: "Passou um trator aqui, derrubou minha casa", e depois no final ela fala: "O meu tio está enterrado aqui, o meu vô ali, e o meu primo ali. Eu conheço tudo aqui, eu sou muito antiga aqui." Então acaba assim. Porque ela fala, "olha eu conheço tudo, eu sei até onde eles estão enterrados". Ela é uma sobrevivente, ela é uma Guarani Kaiowá. Eu tinha esse texto, transcrevi, anotei tudo, e pensei em passar pra pichação. Quando o Paulo Herkenho$\mathrm{ff}^{19}$ veio no Sul, veio me conhecer, e viu esse trabalho. E me incentivou. Ele: "Isso daí daria uma exposição." Aí eu tive que fazer um curso - imagina, eu, que subo nos prédios -, eu tive que fazer um curso pra subir nos andaimes. O museu tinha 6 ou $7 \mathrm{~m} \times 5 \mathrm{~m}$, com letrinhas miúdas, eram umas letrinhas porque era um baita relato. Era uma coletiva, RS XXI - Rio Grande do Sul

19 Crítico e curador brasileiro contemporâneo. 
Experimental, ${ }^{20}$ o nome da exposição, era uma coletiva de artistas do Sul, oito artistas, eu acho.

SS: É, você tá sentadinho ali, um negócio imenso [referindo-se à imagem do trabalho].

IA: Letras do tamanho da sua mão? Então só dá pra ver de perto.

XTJ: É, e o negócio é o seguinte, é in loco, eu fiz como pichação, eu usei uma tinta que depois demoraram pra tirar, eu usei uma tinta de piche, que tu só dá uma mão e fica preto. Aí os guris perguntaram se eu ia pintar de rolinho. Eu: "Não, a gente está dentro de uma instituição, eu vou pintar de pincel." Eles: "De pincel tudo isso aí, cara?" Aí eles foram olhar, todo dia eles iam lá.

IA: Quanto tempo você levou? Três dias?

XTJ: Cinco, porque com o andaime demora muito. Tinha um cara que falava "bota o capacete". Demorava muito, sabe? Eu sempre respeitei. Ele estava trabalhando e ficou bravo porque teve que ficar todos os dias que eu estava ali. Eu ficava até de noite, até fechar o museu, não ia embora às seis, ficava até às dez. Fiz a pichação em guarani, toda. A tradução era do Laércio. O Laércio foi muito legal. Ele sentou aqui e revisou. $\mathrm{E}$ ia uma comunidade lá pra visitar a exposição. Paulo conseguiu o ônibus e alimentação. Então o Laércio disse: "Essa tradução está no meu nome e vai sair num livro, e vai para a comunidade, eles vão ler." Ele falou: "Tu deu o curso pra eles lá, a oficina, eles vão ler isso, eles vão conseguir ler." E foi muito legal porque a gente fez a pichação em guarani, todo mundo que é culto, que frequenta a instituição, não entendeu nada, alguns reagiam com violência - "Que merda isso aqui" -, sabe, porque o Paulo provocou, ele botou na entrada do museu. A primeira parede grande, imensa, era de pichação, e era tão monumental que ela acabava sobressaindo com os vidros do museu, sabe?

Então, quando a aldeia entrou no museu foi legal. Eu me atrasei, eles me esperaram na rua pra entrar todo mundo junto, eram cinquenta guaranis, eles entraram lá e falaram "que legal", a primeira vez deles no museu.

20 Exposição RS XXI - Rio Grande do Sul Experimental, Curadoria Paulo Herkenhoff, Santander Cultural, 2018. 
Figura 9

Xadalu Tupã Jekupé Arqueologia do presente, 2018 Exposição RS XXI - Rio Grande do Sul Experimental, Curadoria Paulo Herkenhoff, Santander Cultural, RS Foto: Luísa Priebe

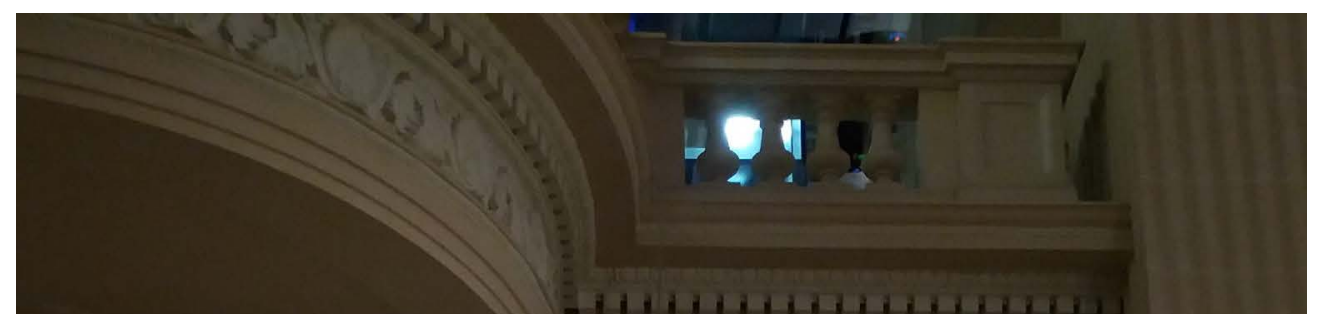

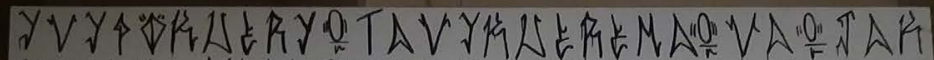

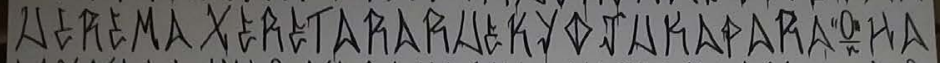

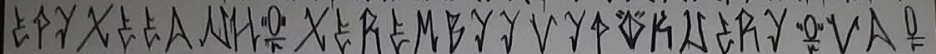

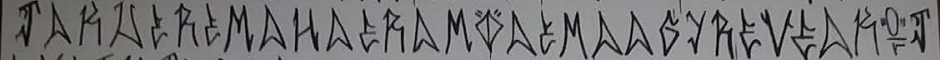

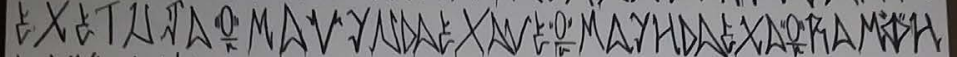

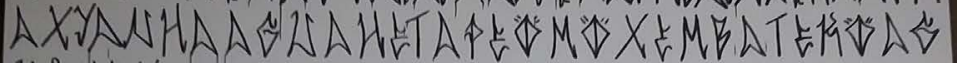

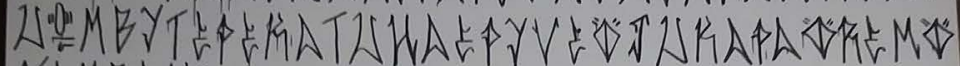

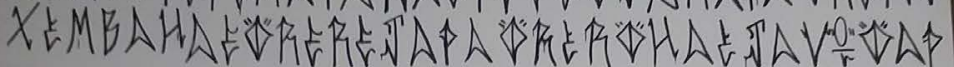

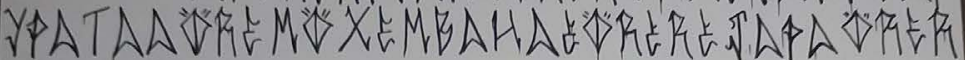
*HA

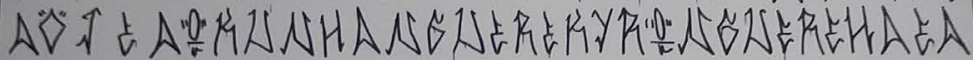

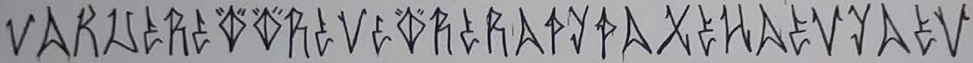

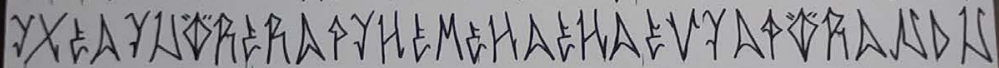

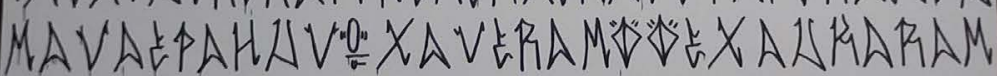

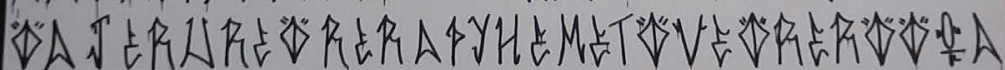

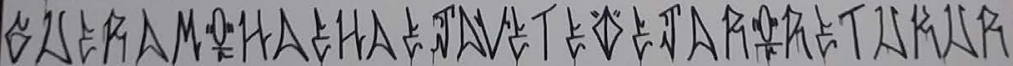
OV

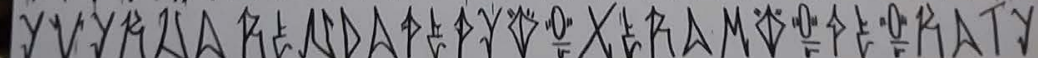

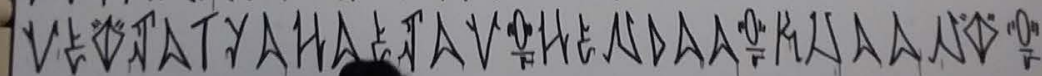

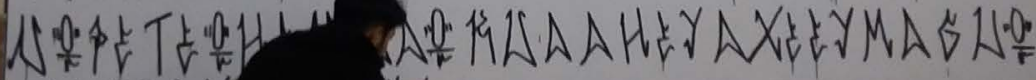
A $-1$ 
E aí eles começaram a ler as pichações, começaram a ler e as pessoas começaram a perguntar, aí um monte de gente começou a perguntar o que é que estava escrito e eles ficaram orgulhosos da língua.

Então, a série "Arqueologia do Presente" é isso, é esse resgate da língua, do antepassado, de coisas que aconteceram e estão acontecendo no sentido marginal, que ainda é transgredir, a pichação. E, pior ainda, pro pichador, é levar a pichação pra galeria, pro museu. Deu uns pequenos problemas, masdepois a gente se acertou, alguns grupos de pichadores não gostaram muito, mas aqui na nossa cidade a gente é fruto da velha escola da pichação, então tiveram que aceitar.

Então, quando a aldeia entrou no museu foi legal. Eu me atrasei, eles me esperaram na rua pra entrar todo mundo junto, eram cinquenta guaranis, eles entraram lá e falaram "que legal", a primeira vez deles no museu. E aí eles começaram a ler as pichações, começaram a ler e as pessoas começaram a perguntar, aí um monte de gente começou a perguntar o que é que estava escrito e eles ficaram orgulhosos da língua.

Então, a série "Arqueologia do Presente" é isso, é esse resgate da língua, do antepassado, de coisas que aconteceram e estão acontecendo no sentido marginal, que ainda é transgredir, a pichação. $E$, pior ainda, pro pichador, é levar a pichação pra galeria, pro museu. Deu uns pequenos problemas, mas depois a gente se acertou, alguns grupos de pichadores não gostaram muito, mas aqui na nossa cidade a gente é fruto da velha escola da pichação, então tiveram que aceitar.

Porque a gente alinha usar o lugar de fala para mostrar um problema. Eu acho que a gente está mais voltado, num tempo remoto, para isso de usar o lugar de fala, tanto meu quanto da comunidade, e eu faço parte da comunidade, para mostrar um problema ou arrumar um jeito de falar no problema. "Olha, vamos ficar atentos que está acontecendo um ataque na aldeia da Zona Sul." É boa essa difusão, que flua, porque aí as pessoas vão sabendo e vão falando, vão falando, e é assim que funciona.

RS: Só pra fechar, que eu sei que a gente está se alongando demais. $\mathrm{Na}$ verdade é uma curiosidade sobre como você vê e como você lida com essa questão do tempo, porque quando você pega o sticker e a street art você tem as matrizes, você reproduz e vai colando e aí é como você falou, 5, 10 segundos, mas daí, quando você faz umas outras obras, como aquela em que você usou estêncil, fio, costura, essa dos planos 
divinos, guarani, não sei, em que você usa costura, colagem, é um outro tempo, já não é o tempo da rua. Mas é um outro tempo que pode ir pro museu, porque já tem um outro tempo, enfim. Eu queria mesmo saber como é que você lida com isso, como é que você enxerga essa questão do tempo, porque realmente tem obras em que você pensa, faz e já vai mostrando os pontos e tem obras em que você vai maturando e vai desenvolvendo e isso leva tempo. Como é que você vê isso?

XTJ: No meu cosmo astral eu sou do Vale dos Tupãs, de pessoas que não têm muita paciência com o tempo, então elas sofrem com o tempo, elas sofrem muito com o tempo. O tempo da rua me deixou muito ansioso, porque na rua tu consegue resolver rápido as coisas; se der confusão vai dar rápido, se eu tiver que colar vai ser rápido, se eu tiver que fugir vai ser rápido. Então eu consigo resolver rapidamente a situação. O tempo dentro de ateliê já é um tempo mais relacionado ao tempo da aldeia, é um tempo de incubação. E não adianta, pra amadurecer uma ideia, tem que ter tempo. Então, dentro da comunidade eles costumam dizer que essa coisa do tempo da rua é meu tempo exterior, meu tempo externo, como pessoa física, esse é o meu tempo, que é um tempo rápido, que eles chamam tempo perecível. E esse outro tempo, que é o tempo de ateliê, é meu tempo interno, então eles acreditam que tu trabalha num tempo pensando que trabalha noutro e nós temos que aprender a trabalhar os tempos na nossa vida. Eu tenho noção que o tempo de ateliê é um tempo interno, é um tempo de amadurecimento e da gestação de ideias, então a gente faz uma gestação da ideia e ela vai sendo criada.

Mas eu estou aprendendo isso ainda, agora, numa parte mais intelectual, da cosmologia; quando eu me sinto muito, muito ansioso eu vou colar as coisas na rua e volto. Eu queria fazer Artes Visuais com o que eu vivo, que é a relação da aldeia e da rua. Mas não tem como fazer isso porque eu acabo sendo o cara do fator social, entendeu? Então, quando eu fui reclamar na aldeia, porque toda hora tem que estar indo lá, eu estou pintando pouco, ele falou: "Ah, e tu pensou que é só pintar, entrou nessa jogada e pensou que ia só pintar." Eu falei: "É, pensei que ia só pintar e ia só colar." E ele: "Isso nem existe. Quem se envolve dessa maneira, se envolve de outra maneira. Então não vai dar pra só pintar", ele falou. E deu outros exemplos, "Queria só tomar chimarrão na beira do fogo, mas eu tenho que buscar a lenha, eu tenho que fazer comida, eu tenho que ajudar a esposa." Ele falou: "Isso é muito lúdico, tu pensar que vai só pintar o que tu vive com a comunidade." Então vai acabar se envolvendo 
com problemas da comunidade pra resolver, porque tu faz parte da comunidade e esses problemas vão gerar até trabalhos se tu quiser, o que eu acho legal.

RS: É mais uma curiosidade. Na apresentação do livro você fala que se identificou com o jabuti e aí eu fiquei curiosa.

XTJ: O jabuti que é a tartaruguinha. Eles chamam aqui tartaruga, olha que legal: "tartaruga tigre". Tem uma história de amor, porque ela tem umas manchinhas. É uma tartaruga muito bonita, e o que parece é que as tartarugas se orientam pela posição das estrelas ou alguma coisa no cosmo, com isso elas conseguem se orientar. Mas o jabuti vive muito tempo, muito tempo, e ele viaja por muitos lugares, ele nunca fica parado num lugar, então ele é um viajante, ele busca, ele carrega muitas histórias no casco por onde ele passa. Então dizem que cada quadradinho do jabuti é uma coisa que tem guardada lá dentro, é uma historinha que tem lá dentro. Então, quando tu olha um jabuti, ele é cheio. E parece que tem uma coisa de coloração do casco que vai dizendo o quanto ele já viveu. Então tem muito a ver com isso na comunidade, do jabuti, que ele ganhou essa dádiva de Deus - Tupã - que ele pode viver por muito tempo, porque ele vai poder contar as histórias por muitas gerações.

transcrição e revisão técnica: Inês de Araujo e Tania Queiroz

Recebido em 22 de março de 2021 e aceito em 22 de março de 2021. 